\title{
Mental Disorders in the Entrepreneurship Context: When Being Different Can Be an Advantage
}

\author{
Johan Wiklund \\ Syracuse University \\ jwiklund@syr.edu \\ Isabella Hatak \\ University of St. Gallen \& University of Twente \\ isabella.hatak@unisg.ch \\ Holger Patzelt \\ Technical University of Munich \\ patzelt@tum.de \\ Dean A Shepherd \\ University of Notre Dame \\ dshephe1@nd.edu
}

Acknowledgement: We would like to thank the participants of the Entrepreneurship and Mental Health workshop at Syracuse University, October 2016 for valuable comments and suggestions. 


\section{INTRODUCTION}

Given the prevalence of mental disorders in society and their far-reaching implications, improving mental health is one of the grand challenges of our time (Grand Challenges Canada, 2016). Estimates show that around the world, more than one-quarter of the population has some form of mental health problem at some point in life, and this number is increasing, with mental health issues forecasted to be the second leading illness (behind heart disease) by 2020 (WHO, 2001). For example, mental disorders were identified as the most significant cause of unemployment in Sweden and are a major factor hampering economic growth in the country (OECD, 2013). As this example shows, the costs of mental disorders to society appear to be substantial (Kessler et al., 2009).

While mental disorders place a considerable burden on a nation's healthcare system and economy, the costs are more acutely felt by the individual suffering from the mental disorder and his or her loved ones. Individuals with mental disorders not only face reduced psychological well-being directly from their disorder, but also feel the consequences indirectly through the disorder's negative impact on their careers, relationships, and opportunities for personal growth.

The evidence above paints a gloomy picture for those with mental disorders, for their loved ones, and for society as a whole. However, we propose, as a counterweight to the dominant perspective in the literature, a different picture-one that is light, hopeful, and valued-by considering mental disorders in entrepreneurship. We believe that exploring the link between mental disorders and entrepreneurship is worthwhile for several reasons.

First, what is functional and dysfunctional in terms of human characteristics and behavior is largely a matter of context. This is reflected in the person-environment (P-E) fit literature, which states that people are attracted to work environments that present work cultures, values, requirements, and demands that match their own personalities, needs and skills (Kristof, 1996; Kristof-Brown et al., 2005). For example, it is a common belief-supported by research evidence - that certain severe mental disorders are functional within creative professions (Kyaga 
et al., 2011). Many people excelling in the arts appear to show signs of mental disorders and may have underperformed if they had they chosen a different career.

Second, entrepreneurs have great leeway to craft their jobs to fit their own idiosyncratic needs and abilities (Miner, 1994; Baron, 2010). By undertaking an entrepreneurial endeavor, people can craft their work tasks and work environments to suit their personal needs and preferences in ways that may be difficult in regular employment. This is likely of particular importance for people whose needs and preferences deviate substantially from the norms, such as among those with mental disorders. For example, somebody suffering from agoraphobia may have to work from home, which would be hard to accommodate for many employers. Therefore, entrepreneurship may be a better job option than traditional employment for people with certain mental disorders.

Third, under some circumstances, people with certain mental disorder may even do better in entrepreneurship than individuals without these disorders Indeed, in a recent qualitative study entrepreneurs with ADHD diagnoses reported that they felt they fit better in self-employment than in regular employment and even believed their ADHD symptoms provided them an advantage over those without ADHD (Wiklund, Patzelt \& Dimov, 2016). Similarly, a qualitative study by Lasky et al. (2016) revealed that highly stimulating work tasks—-tasks that are novel, intrinsically interesting, and requiring multitasking in a fast-paced environment (consistent with the characteristics of entrepreneurial tasks) —ameliorate ADHD symptoms among young adults. It appears possible that the very symptoms and traits associated with certain disorders may be advantageous and provide benefits in the performance of some entrepreneurial tasks. Indeed, that disorders can be associated with strengths as well as weaknesses is not totally new. For example, psychologists have associated dyslexia with more original thinking (Tafti et al., 2009), ADHD with sensation seeking (White \& Shah, 2011), bipolar disorder with perseverance (Hayden et al., 2008), and autism with pattern identification (Baron-Cohen et al., 2009). Recently, scholars have directly examined the connection between psychological disorders and entrepreneurship, finding 
positive associations between entrepreneurship and dyslexia (Logan, 2009), bipolar traits (Johnson et al., 2018), ADHD (Wiklund et al., 2017a), and mood disorders (Bogan et al., 2013).

In this paper, we build on the general tenets of the P-E fit literature that individuals can flourish in the appropriate environments, and believe that entrepreneurship can offer unique opportunities for workplace accommodations to accomplish environmental fit for people with a wide range of mental disorders. However, given the large number of mental disorders and their great heterogeneity (see APA, 2013), as well as the great heterogeneity in the tasks of an entrepreneurial endeavor (see Crawford et al., 2015), it is not possible to cover in detail all possible associations between mental disorders and entrepreneurship. The greatest contribution likely lies in exploring the most extreme (and the most interesting) cases when there could be a positive association between disorders and entrepreneurship. A focus on possible positive implications of otherwise negative individual characteristics stands to make novel contributions. Indeed, entrepreneurship research has overwhelmingly focused on positive implications of positive individual characteristics (e.g., Frese \& Gielnik, 2014), whereas clinical psychology mainly focuses on the negative implications of mental disorders. Therefore, our intention with this paper is to propose that researchers explore the role of mental disorders in entrepreneurship to develop novel insights and theories in entrepreneurship and to contribute back to theories on the psychology of work, career choice, and perhaps clinical psychology. In focusing on what people with mental disorders can accomplish in entrepreneurship, we also hope to advance the strength-based approach to mental disorders.

This paper proceeds as follows: First we provide a brief introduction of mental disorders and review the limited research on mental disorders in entrepreneurship. Second, we build on the previous section to offer opportunities for future research that we believe can make important contributions to the entrepreneurship literature and hopefully contributions to the literatures on psychology, decision making, affect, and career choice. In this regard, we also discuss methodological opportunities for investigating mental disorders in entrepreneurship. Finally, we offer concluding remarks. 


\section{REVIEW: MENTAL DISORDERS IN ENTREPRENEURSHIP}

"A mental disorder is a clinically significant disturbance in an individual's cognition, emotion regulation, or behavior that reflects a dysfunction in the psychological, biological, or developmental processes underlying mental functioning. Mental disorders are usually associated with significant distress in social, occupational, or other important activities.” [The American Psychiatric Association (APA)]

The range of conditions that meet the criteria for a mental disorder are extensive. The Diagnostic and Statistical Manual of Mental Disorders $5^{\text {th }}$ Edition (DSM-5 [APA, 2013]) lists 157 different mental disorders that vary in severity, permanency, treatment, and responsiveness to therapy. The diagnoses of mental disorders are based on interviews; behavior observations; and various special assessment tools, including questionnaires and behavioral tests (APA, 2013) used by psychiatrists, psychologists, pediatricians, and/or social workers. Unlike in many other fields of medicine, mental disorders are conceived of in terms of syndromes, i.e., clusters of correlated symptoms rather than their underlying causes, which often remain unknown. There is a limited number of studies that have investigated mental disorders in entrepreneurship, which we categorize in terms of job design, occupational choice, neuroscience, and coping/resilience.

\section{Job Design, Mental Disorders, and Entrepreneurship}

Stress has implications for mental health (D'Angelo \& Wierzbicki, 2003; Parrish et al., 2011; Schoenfeld et al., 2016). The Job-Demand-Control (JDC) model highlights how job demands and job control influence stress (Karasek, 1979). Entrepreneurship is often associated with high job demands, but because entrepreneurs have high job control, these demands may not lead to high stress (Stephan \& Roesler, 2010). Therefore, entrepreneurs may experience less stress over the long run, which can potentially reduce the onset of some mental disorders (see Stephan \& Roesler, 2010) or make entrepreneurs otherwise resilient to stress-related mental disorders (Baron et al., 2016). 
Empirical studies have largely focused on stress-related mental disorders, such as anxiety and depression. Evidence appears mixed regarding whether entrepreneurs experience more or less stress then employees and show more or less signs of anxiety and depression (Rauch et al., 2017; Stephan, 2018). For example, it appears that stress is higher for entrepreneurs after entry into self-employment than before entry as indicated by increased use of sedative/hypnotic medication (Dahl et al., 2010). However, this literature has not examined other, non-stress related, disorders that may be particularly relevant for entrepreneurship.

\section{Occupational Choice, Mental Disorders, and Entrepreneurship}

Some recent research on the prevalence of mental disorders in entrepreneurship has attempted to separate the "selection" effect into entrepreneurship from the "treatment" effect of working as an entrepreneur by applying an occupational choice lens (e.g., Bogan et al., 2013; Rietveld et al., 2015). An occupational choice lens highlights how people maximize utility by comparing the expected present value of different occupational alternatives' economic and psychic benefits and then choose the occupation that gives them the greatest utility (e.g., Becker, 1976). Applied to the entrepreneurship context, this theory has been used to explain individuals' choice between self-employment and paid employment (e.g., Eisenhauer, 1995; Douglas \& Shepherd, 2002; Lévesque et al., 2002). In the case of people with mental disorders, similar to the job-design approach reviewed above, the argument can be made that entrepreneurship offers individuals greater latitude in crafting their work in ways that suit their individual special needs (Haynie \& Shepherd, 2011; Bogan et al., 2013). Indeed, because of greater job control and flexibility, entrepreneurship likely offers people with mental disorders the chance to better capitalize on their strengths while balancing their weaknesses, thereby increasing the relative utility of entrepreneurship for such individuals. Moreover, the opportunity cost of foregoing paid employment could be expected to be lower among people with mental disorders because such jobs are poorly adapted to their needs, which further increases the relative utility of entrepreneurship. Applying a similar logic, Bogan and colleagues (2013) found that women with 
a mood-related diagnosis, such as depression or bipolar disorder, were more likely to select into entrepreneurship by starting unincorporated businesses.

However, there are doubts about the nature of the relationship between mental disorders and self-selection into entrepreneurship. For example, most Western countries have some form of collective bargaining, such that salaries in paid employment are not necessarily a direct reflection of a worker's productivity (Iversen et al., 2010). In entrepreneurship, however, rewards are often more reflective of an individual's performance (Douglas \& Shepherd, 2000). Moreover, pension benefits and social security are typically more generous for individuals in employment than for those in entrepreneurship (Hatak et al., 2013). For these reasons, paid employment may be relatively more attractive to low performers in the labor market, whereas entrepreneurship is more attractive to high performers. Furthermore, health problems, including mental disorders, are likely to lead to reduced labor market productivity, which may increase the attractiveness of the buffers and shelters provided by paid employment relative to the more vulnerable position of self-employment. Although there is some evidence that healthier individuals select into self-employment, the findings for mental health have not been statistically significant (Rietveld et al., 2015).

These early studies have not distinguished between the different symptoms associated with different mental disorders and the ways these differences impact the utility of different career alternatives. For example, the work implications of substance abuse, depression, anxiety, ADHD, and autism are likely very different and thus likely impact the choice between paid employment and entrepreneurship. The type of disorder will also likely influence the type of entrepreneurship (e.g., opportunity-driven versus necessity-driven entrepreneurship, lifestyle firm versus high-growth venture) or industry chosen. Without sufficient consideration of the type of mental disorder and the fit of different disorders with the nature of different career alternatives, it is not surprising that empirical findings are generally quite weak and inconsistent. While we largely view entrepreneurship as a choice, societal norms can push some individuals into entrepreneurship. Specifically, while stigma appears to be a universal phenomenon (Link et 
al., 2004), the practices and outcomes of stigmatization such as prejudice or discrimination differ across cultures (Yang et al., 2007; Overton \& Medina, 2008). Consequently, employers that are embedded in cultures where it is normative behavior to perceive people with mental disorders as unpredictable or even dangerous are less likely to select such people as their employees, implying higher levels of necessity-driven entrepreneurship. Next, we highlight research more focused on specific mental disorders.

\section{Neuroscience, Mental Disorders, and Entrepreneurship}

Recent advances in neuroscience have suggested a neurological basis for several mental disorders. As such, some mental disorders are associated with structural brain differences (Hoogman et al., 2017), which have genetic origins (e.g., Katragadda \& Schubiner, 2007). Some consider these structural differences to represent natural variation (e.g., Ortega, 2009; Jaarsma \& Welin, 2012). Despite competitive pressures, these brain differences have remained in the gene pool throughout evolution, which has led to the coining of the concept of neurodiversity (Singer, 1999). According to this view, there are likely also positive implications of these brain differences because otherwise they would have been selected out through the process of evolution.

In the discussion about neurodiversity, there is an emerging strength-based approach to mental disorders. This approach centers on systematically examining the strengths of individuals with mental disorders and then modifying environments to lever these strengths. An interesting example of this strength-based approach occurred at the software company SAP. In 2013, SAP announced that they intended to hire hundreds of people with autism spectrum disorder to work as software testers. This recruitment strategy originated in the notion that people with autism have specific strengths and abilities that make them very well suited for specific work tasks. The company estimated that by 2020, $1 \%$ of its 65,000-person workforce would have some form of autism (Huffington Post, May 22, 2013).

While there has been little research taking a strength-based approach in the entrepreneurship context, there are exceptions. Nicolaou and colleagues (2011) proposed that 
dopamine receptors associated with increased novelty seeking and risk taking are directly related to an increased propensity for choosing to become an entrepreneur because entrepreneurship involves novelty and risk taking. Other research has found that children with ADHD are more likely to be self-employed in adulthood (Mannuzza et al., 1993), that students exhibiting ADHD traits have higher entrepreneurial intentions (Verheul et al., 2015), and that small business owners with ADHD symptoms have a higher entrepreneurial orientation (Thurik et al., 2016).

Further, researchers have suggested that dyslexia is associated with inherited (Fisher \& Francks, 2006) brain differences (Eden et al., 1996). It appears that in dyslexia, deficits in the left brain hemisphere are compensated by strengths in the right hemisphere (e.g., Karolyi et al., 2003), such as spatial ability, pattern recognition, and intuition (Galaburda, 1993). These righthemisphere brain strengths exhibited by dyslexics are likely valuable in business generally (Kirk \& Reid, 2001) and in entrepreneurship specifically (Logan, 2001). Indeed, one study found that dyslexia was more common among entrepreneurs than among managers and that entrepreneurs with dyslexia grew their businesses faster than entrepreneurs without dyslexia (Logan, 2009). Although these findings support the notion of a positive relationship between dyslexia and entrepreneurial action, a more recent study with a larger sample found a small, statistically nonsignificant relationship between dyslexia and entrepreneurship (Hessels et al., 2014).

\section{Coping and Resilience, Mental Disorders, and Entrepreneurship}

To achieve success at school and in their social and professional lives, individuals with mental disorders must develop coping and compensatory strategies for overcoming adversity. These strategies can translate into skills that are transferable across contexts, including into entrepreneurship (Everatt et al., 1999; Miller \& Le Breton-Miller, 2017). That is, individuals who overcome the challenges associated with mental disorders are likely to have developed skills and resources that enhance their resilience-defined as the process by which an individual builds and uses his or her capability endowments to interact with the environment in a way that positively adjusts and maintains functioning prior to, during, and following adversity (Williams et al., in press). 
Logan (2009) found that entrepreneurs with dyslexia used compensatory strategies developed early in life to successfully delegate, communicate with, and motivate employees as well as to make intuitive decisions. Thus, the coping skills individuals with dyslexia learn in their formative years can become important capabilities for engaging in entrepreneurial tasks (Logan \& Martin, 2012), supporting self-belief in an ability to overcome challenges, and thus making them more tolerant of risk (Miller \& Le Breton-Miller, 2017). Similarly, children with ADHD often struggle in school and those who make it into college exhibit greater resilience to adversity than students without the condition (Wilmhurst et al., 2011). Or, as Archer (2014) put it,

"It's worth noting that some of [ADHD's] most common characteristics-creativity, multi-tasking, risk taking, high energy, and even resilience-are, in fact, strengths when leveraged in the right way and in the right career . . . [those with ADHD] are at their best in crisis mode, multi-tasking and free-associating to intuitively reach a solution.”

Resilience is valuable in entrepreneurship as individuals often need to persevere through the challenges and setbacks faced during the entrepreneurial process (Hmieleski \& Carr, 2008; Hayward et al., 2010), thus making failure a less feared or traumatic experience (Miller \& Le Breton-Miller, 2017). Given the challenges associated with the entrepreneurial process, being able to tolerate challenges and obstacles and having the energy to persist as a result of coping with a mental disorder may not only be beneficial but essential for entrepreneurial success.

\section{Recap of the Literature}

Mental disorders may impact entrepreneurial action by influencing individuals’ preferences for an entrepreneurial career, by bestowing them with characteristics conducive to entrepreneurial tasks (e.g., creativity, risk tolerance), and by triggering coping and resilience to stressors associated with the entrepreneurial process. While some initial empirical support indicates a link between some mental disorders and entrepreneurship, this research is sparse, and the results are largely inconclusive. We will now highlight avenues for future research on mental 
disorders in entrepreneurship that we believe can make important contributions to the entrepreneurship literature and beyond. As noted earlier, we focus mainly on disorders that may actually have positive implications in entrepreneurship. We summarize our reseach agenda in Figure 1.

*** Figure 1 about here $* * *$

\section{FUTURE RESEARCH: MENTAL DISORDERS IN ENTREPRENEURSHIP}

\section{Research Opportunity 1: When Positive is Bad and Negative is Good for Entrepreneurs}

People with mental disorders are, by definition, psychological outliers. To some extent, entrepreneurs are also outliers, and more research is needed on the overlap between these two groups. For example, the energy levels, extraversion, risk taking, self-esteem, and optimism exhibited by individuals with bipolar disorder in the hypomanic state resonates with several variables that have received substantial attention in the entrepreneurship literature (see above and Frese \& Gielnik, 2014). However, given that a focus on disorders typically involves outliers (i.e., extreme levels of specific variables), it is important to consider at what levels variables are beneficial in entrepreneurship and at what levels they become dysfunctional. For example, does "too much of a good thing” apply to some of the psychological variables previously considered to be generally positive when applied in entrepreneurship? Generally, it seems that when a strength is overplayed, there is a risk of diminished capacity on the opposite pole, with such overuse turning strengths into weaknesses (Kaplan \& Kaiser, 2009). For instance, while selfefficacy generally shows positive associations with entrepreneurial outcomes such as business creation and performance (Rauch \& Frese, 2007), there might be darker outcomes when we consider the highly optimistic self-perceptions that are characteristic of individuals with ADHD (Anthsel, 2017). The investigation of extremely high or low levels of psychological variables by studying individuals with mental disorders in conjunction with specific entrepreneurial 
outcomes, such as (incremental versus radical) product or service innovation, ${ }^{1}$ increase in turnover, and employee growth, or-in the course of venturing beyond the conventional outcome variables associated with generating economic gains for the entrepreneur, such as the generation of societal value or preservation of the natural environment-will enable the careful examination of the potentially detrimental influences of variables that have generally been viewed as positive in entrepreneurship. In addition, such an investigation will provide the opportunity to contribute to more general theory by establishing new boundary conditions or by altering theory to extend its boundary conditions.

Additionally, it seems likely that extreme values of well-researched psychological variables are positively associated with some activities essential to the entrepreneurial process, including identifying, and acting on potential opportunities, but are negatively associated with other aspects of the entrepreneurial process such as assessing the potential value of opportunities. In this regard, Lerner (2016) found that while action-promoting ADHD disinhibition positively affected potential resource providers’ inferences about entrepreneurs’ “generative qualities” (i.e., being creative, visionary, good at idea generation, and good at recognizing opportunities), it made potential resource providers wary of aspiring entrepreneurs' "administrative qualities” (i.e., being consistent, reliable, good at defining next steps, and implementing ideas). Moreover, extremely high self-esteem, such as associated with narcissism (Grijalva \& Harms, 2014), may be excellent for taking the plunge to engage in entrepreneurial activity but may be detrimental to interpreting negative performance feedback, leading to an escalation of commitment to a losing course of action (Grijalva \& Harms, 2014). For the leadership context, it has been shown that narcissism has a curvilinear association with leadership effectiveness (Grijalva et al., 2015), thus appearing to be neither wholly beneficial nor detrimental. Furthermore, while risk-taking propensities may foster business creation, extreme levels of risk-taking —as found among those

\footnotetext{
${ }^{1}$ We define innovation as "new ideas, novelty, experimentation and creative processes that may result in new products, services, and technological processes“ (Lumpkin \& Dess, 1996: 142).
} 
with bipolar disorder (Johnson et al., 2018) — may conflict with financial stability and may be detrimental to financial firm performance (Kreiser et al., 2013). Do individual-level variables found to be positively associated with entrepreneurial outcomes become negative at extremely high or low levels for different entrepreneurial activities? In order to come up with sound implications regarding the link between individual-level variables and specific outcomes in entrepreneurship, not only should we distinguish between different dimensions of entrepreneurial success but also separate entrepreneurial action into its key activities (i.e., thinking of entrepreneuring as a series of activities in the entrepreneurial process [Shepherd \& Patzelt, 2017] such as such as obtaining financial backing, purchasing equipment, organizing teams, servicing customers, marketing and engaging in innovation). The more we challenge the assumption of a monolithic entrepreneurial action and begin to investigate the nature of different stages of the entrepreneurial process and the key activities in conjunction with individual-level variables, the better situated we will be to find the "best person-job fit," especially for entrepreneurs with mental disorders.

In turn, do individual-level variables shown to be negatively related to entrepreneurial outcomes become positive at extremely high or low levels of that variable for different entrepreneurial activities? At this stage, research in entrepreneurship has focused on the upside of being an entrepreneur and on psychological variables, but "the negative aspects of the entrepreneurial personality have been largely ignored” (Miller, 2015: p. 1). As such, we encourage researchers to pay greater attention to counterintuitive relationships that have the potential to make more substantial theoretical contributions (Davis, 1971) by investigating psychological variables that are generally considered to have negative implications for individuals, economies, and societies but may actually be positive in entrepreneurship. Therefore, explorations outside the set of variables positively related to general human endeavors that instead focus on the characteristics of mental disorders could provide an alternative route for increasing our understanding of the psychology of entrepreneurship. For example, while bipolar disorder has been associated with symptoms like aggression, disorganized thought, and 
recklessness that emerge as mania spirals upward (Johnson et al., 2017), those with bipolar disorder are generally very willing to persevere on difficult tasks (Hayden et al., 2008), a behavioral tendency that is critical to entrepreneurial success (Hmieleski \& Carr, 2008; Hayward et al., 2010). We hope that future research will move from investigating normal levels of variables in moderate contexts to investigating non-normal levels of variables in extreme contexts to theorize and find matches and mismatches and thereby push the boundaries of existing theories and/or sow the seeds for the creation of new interesting and relevant theories of entrepreneurship. We also note that the boundaries outlined in this section also apply to the following research opportunities, to which we now turn.

\section{Research Opportunity 2: Mental Disorders and Entrepreneurial Career Decisions}

People with mental disorders make decisions in specific ways, which can influence the decisions they make regarding entrepreneurial entry and exit. For example, impulsivity is a defining feature of many disorders which might lead to unusually quick entry and exit decisions without much consideration of available information and/or the consequences of those actions (see e.g., Anthsel, 2017; Gunia, 2017; Johnson et al., 2018; Lerner et al., 2018; Wiklund et al., 2017a; 2017b). Wiklund and colleagues (2017b) suggest that in high uncertainty entrepreneurial contexts, such rapid, impulsive decision making can be functional, which has been empirically corroborated (Wiklund et al., 2017a).

Moreover, impulsivity related to mental disorders might constitute an important boundary condition to known antecedents of entry and exit decisions. For example, a considerable body of research has highlighted that entrepreneurs often experience high levels of passion for their ventures (e.g., Cardon et al., 2009; Chen et al., 2009) and often persist with their ventures despite underperformance (Gimeno et al., 1997; Hoang \& Gimeno, 2010). Such entrepreneurs tend to view their ventures as an expression of their identity or concept of self (Fauchart \& Gruber, 2011), and persisting despite underperformance allows them to at least partly avoid the feelings of loss and negative emotions associated with exit (Byrne \& Shepherd, 2015; Shepherd et al., 2016; Hessels et al., 2018). Exploring how impulsivity related to mental disorders impacts 
passion, persistence, and/or feelings can increase our understanding of the importance, role, and nature of mental disorders for entrepreneurial career decisions and for individuals' chosen entrepreneurial identity, thus helping to differentiate between those who start their firms because of economic self-interests and those who start their firms because of concern for others.

Further, given studies emphasizing the value of planning for entry (Shane \& Delmar, 2004; Gruber, 2007), studying successful entrepreneurs with mental disorders might provide a unique context for exploring counter-intuitive strategies for thinking about the future that do not involve planning (that involve very low levels of planning or no planning at all). Specifically for the decision to enter an entrepreneurial career, "typical” thinking involves anticipating different outcomes and the level of regret one may feel for an error of commission vis-à-vis an error of omission, which may reverse an otherwise rational decision (i.e., a decision based on the payoff matrix [Loomes \& Sugden, 1982]) (for the relationship between anticipated regret and start-up behavior, see Hatak \& Snellman, 2017). Do individuals with impulsivity caused by a mental disorder engage in the same thinking when anticipating feelings of regret over the different alternatives? If individuals with impulsivity-related mental disorders do not anticipate varying levels of regret for the different alternatives, it is possible that there are situations in which a reduced role of regret in the decision-making process leads to a better (more rational) decision. Indeed, there is some evidence that entrepreneurs engage in less counterfactual thinking than managers and, as a result, display less hindsight bias, thus enabling them to admit their mistakes and learn from them (Baron, 2000). Studying impulsivity might provide insights into why some engage in less counterfactual thinking and in which situations such impulsivity leads to superior decision and/or learning outcomes.

Furthermore, people with dyslexia (Galaburda, 1993), including entrepreneurs (Logan, 2009), tend to make decisions largely based on intuition rather than systematic analysis. Although the entrepreneurship literature has theorized on the important role of intuition in new venture creation (e.g., Mitchell, Friga, \& Mitchell, 2005; Blume \& Covin, 2011), Blume and Covin (2011, p: 138) concluded that because "of the difficulties associated with measuring 
intuition (Simon, 1987; Sinclair \& Ashkanasy, 2005) throughout the venture founding process, examinations of the actual use of intuition among entrepreneurs will likely remain rare within the realm of entrepreneurship research.” Studying those high on impulsivity could be a way to explore intuition's role in entrepreneurial decisions because these individuals may be more readily identifiable and more extreme in their reliance on intuition. Such research could thus provide an opportunity to extend the boundaries of current theories on intuition in entrepreneurship and on intuition more generally. For example, given the difficulty of communicating intuition to others (Dane \& Pratt, 2007), it is likely useful to investigate those with high reliance on intuition (e.g., individuals with dyslexia) to determine if they use any special communication strategies for articulating their intuition or rallying others behind their intuitive thoughts and actions. These strategies for communicating intuition could become a useful tool for entrepreneurs who do not have a mental disorder and who at times need to communicate their intuition about potential opportunities or new venture strategies to stakeholders. As these theories are developed, there is the possibility that they will be generalizable to other individuals (with or without mental disorders) in contexts of high uncertainty, such as decision making by firefighters, basketball coaches, and parents.

\section{Research Opportunity 3: Mental Disorders and Opportunity Identification and Evaluation}

Mental disorders differ in how they influence individuals' allocation of attention to environmental stimuli. For example, ADHD is known to broaden individuals' attention (Kasof, 1997), which can facilitate the recognition of new entrepreneurial opportunities (Shepherd et al., 2007; Baron \& Tang, 2011; Shepherd et al., 2017). Furthermore, individuals with some mental disorders, such as bipolar disorder (Eckblad \& Chapman, 1986) and ADHD (Corbisiero et al., 2017), experience unusually high positive affect, which can also facilitate opportunity recognition (Baron, 2008). Given that other prerequisites for opportunity recognition are met (e.g., entrepreneurs possess the necessary knowledge and motivation [McMullen \& Shepherd, 2006] and social networks [Ozgen \& Baron, 2007]), studying entrepreneurs with ADHD or bipolar disorder might reveal insights into how attention is generated, focused, and allocated to 
form large opportunity sets (given broader attention, creativity, and/or positive affect), opportunity sets larger than those captured in prior entrepreneurship research based on typical entrepreneurs. Exploring the process of generating large opportunity sets could have substantial theoretical and practical implications. For example, larger opportunity sets at venture formation have been associated with superior performance and growth in the long run (Gruber et al., 2008; 2013). However, it is also possible that opportunity sets that are too large make it difficult to select (or slow the selection of) an opportunity for exploitation. When do opportunity sets become too large to be evaluated effectively, and/or are they evaluated differently by those with mental disorders than by those without? Perhaps intuition, which is widely used for decision making by those with ADHD and individuals with dyslexia (Logan, 2009), is important to effectively deal with opportunity sets that are too large to be analyzed systematically within an appropriate amount of time. That is, perhaps one benefit from the symptom of a mental disorder (i.e., a larger opportunity set) is magnified by another symptom of the same or a different mental disorder (i.e., intuitive decision making) to enhance performance on an entrepreneurial task, such as opportunity identification and evaluation.

Over and above the size of an opportunity set, the nature of the opportunities within the set might be different for people with mental disorders. For example, both bipolar disorder (Jamison, 2005) and ADHD (Kasof, 1997) have been associated with higher levels of creativity, suggesting that people with these disorders may generate opportunities that are more novel. Similarly, many individuals with dyslexia develop unusual right-brain capabilities having to do with creativity and superior interpretive capability (Snowling, 2000), and they often generate original ways of questioning and redefining situations, which may enable them to identify opportunities others fail to even imagine (Logan \& Martin, 2012). Similarly, the literature on sub-clinical psychology suggests that teams with medium levels of narcissism are more creative than those with low levels, and that there is an optimum number of narcissists on a team with respect to systematic thinking (Goncalo et al., 2010). Psychoticism has also been found to be associated with creativity (Eysenck, 1993). In short, the creativity associated with some mental 
disorders might be a valuable asset in entrepreneurial teams (see Johnson et al., 2018), enabling thinking that is unconstrained.

Indeed, studying the upper tail of the "creativity distribution” triggered by some mental disorders will likely reveal new theoretical insights into opportunity identification and evaluation processes. In this regard, adopting an interaction perspective of opportunity may be useful, allowing us to consider the potential opportunity as not only belonging to the domain of the initial entrepreneur's mind, but also to the domain of the environment (Shepherd, 2015; Shepherd \& Patzelt, 2017). As such, opportunities are subject to modification as they enter and re-enter the environment, with the environment impacting their usefulness. For example, to what extent is having a set of highly novel opportunities useful? On the one hand, high novelty may lead to the identification of radical innovation opportunities. On the other hand, the potential opportunity might be so novel to the entrepreneur and his or her team that they have a difficult time evaluating and/or exploiting it. Although firms need a balance between exploration and exploitation and there is a tendency for firms to drift toward exploitation (March, 1991), it could be that mental disorders associated with creativity lead the entrepreneur's firm to drift toward exploration (and out of "balance”). A solution might be that entrepreneurs with the ability to generate highly novel potential opportunities enter industries in which radical innovations are rewarded and avoid industries in which incremental improvements or exploitation are key success factors.

The high-tech industry may constitute such an environment where the ability to identify radical innovation opportunities pays off. In general, industries that are less institutionalized and more open to behavioral differences (i.e., less stigmatization), are likely more suitable for entrepreneurs with mental disorders. New, rather than established industries (Aldrich \& Fiol, 1994) may be more accommodating of entrepreneurs with mental disorders. Specifically, in the context of founding of a completely new activity, in an institutional void, the structural determinants of mental disorder stigma that would arise from economic, political, and historical sources are rather weak (Corrigan et al., 2004). Consequently, in new industries there is likely 
less institutional discrimination against entrepreneurs with mental disorders (Yang et al., 2007). More can be done to find the right fit between the entrepreneur with a mental disorder and the business environment he or she chooses to enter. Moreover, studying mental disorders in conjunction with founder identity might provide insights into why some ventures put strategic emphasis on creating market disequilibrium while others focus on exploiting strategic resources.

\section{Research Opportunity 4: Mental Disorders and Organizing Entrepreneurial Activity}

People with mental disorders may also have specific ways of organizing. By organizing, we refer to entrepreneurs' dividing of tasks among venture members and the entrepreneurial team and integrating their efforts (Puranam et al., 2014). Entrepreneurs with some mental disorders have difficulties with tasks that require sustained mental effort, such as financial and strategic planning, systematic analysis of markets and competitors, or long and detailed negotiations with stakeholders. Entrepreneurs with limited ability to sustain mental effort will likely need to rely on other team members to perform such tasks for them (Lerner et al., 2018; Miller \& Le Breton Miller, 2017), even though such tasks are central to the development of the new venture. In turn, the literature on sub-clinical psychology has found that narcissists are effective in impression management (Back, Schmulke, \& Egloff, 2010), which can help entrepreneurs secure the support of stakeholders (Zott \& Huy, 2007).

The defining characteristics of narcissists, which include a "pervasive pattern of grandiosity" coupled with a "need for admiration and lack of empathy” (APA, 2000, p. 717), might seem intuitively negatively related to stakeholder support. However, the air of visionary boldness that is a hallmark of narcissism can inspire followers (e.g., employees, customers, venture capitalists) to support a narcissist (for an overview see e.g., Rosenthal \& Pittinsky, 2006). Especially under high uncertainty, which characterizes entrepreneurship, people often long for someone communicating a clear sense of direction. Here, the narcissistic entrepreneurs' confidence and visionary boldness can be critical in garnering stakeholder support. Under such uncertain conditions, narcissistic entrepreneurs may be able to direct stakeholders' attention to opportunities for change, increase optimism regarding change, and mobilize their resources 
(Campbell, Hoffman, Campbell, \& Marchisio, 2011). Consistent with previous theorizing in the narcissism literature (Robins \& Beer, 2001), we therefore suggest that the positive characteristics associated with narcissism can yield short-term benefits in terms of stakeholder support. However, when the venture matures and the era of brief acquaintanceships is over, the narcissistic entrepreneurs' negative characteristics such as lack of empathy for others and thereby their attitude of 'working for themselves' instead of 'working for the firm' may come to the fore and are likely to harm long-term stakeholder support (Hatak \& Ehrenhard, 2017). Exploring the effects of narcissism under different conditions and over time is important when considering the extent to which narcissism in entrepreneurship is good or bad.

To what extent do entrepreneurs with mental disorders understand and acknowledge their limitations and hire people to "fill in” their mental gaps? It would be interesting to understand the hiring, selection, and other HR management strategies and practices of entrepreneurs with different mental disorders. For example, what are the attributes of the person who complements an entrepreneur's particular mental disorder, how is his or her work strategically managed by the entrepreneur with a mental disorder (e.g., is there more emphasis on empowerment-enhancing HR practices to better balance the entrepreneur's specific weaknesses as compared to skillenhancing or motivation-enhancing [rewards, bonuses] HR practices [Rauch \& Hatak, 2016]), and what challenges do these "complementors" face? For instance, those working for an entrepreneur with a mental disorder may need to be highly adaptable to extremes in the entrepreneur's work effort (e.g., periods of working without sleeping for bipolars [Gardner et al., 2006]) and to his or her tendency to make impulsive and unpredictable decisions [Wiklund et al., 2017b]).

Indeed, integrating employees' efforts seems to be particularly challenging when the entrepreneur has a mental disorder because it is unlikely that the typical means of collaboration and coordination (described in the current literature and learned through education and typical experience) will work. Perhaps the complementor is someone in the middle of the distribution who can provide a typical perspective for the entrepreneur (at the tail) and provide typical 
interactions with the venture's stakeholders. However, perhaps the complementor is on the tail opposite the entrepreneur, and together, the mean is somewhat "normal." We suspect, however, that this averaging effect is unlikely to work because the two team members would be so different that there is insufficient common ground to understand each other. In this way, perhaps the complementor is at the upper bounds of "normal" on the aspect for which the entrepreneur is at the tail because the complementor can then understand and communicate well with the entrepreneur but is "typical enough" to help the venture overcome challenges stemming from the entrepreneur's mental disorder. Studying this dyadic (and even team-oriented) approach to "managing" mental disorders in entrepreneurial ventures is likely to make an important contribution to the entrepreneurship literature and hopefully also to the literatures on team diversity and management.

Conversely, it would also be interesting to better understand which hiring, selection, and other HR management practices are useful for entrepreneurs without a mental disorder to hire people with mental disorders in order to effectively harness their strengths. A good example is Specialisterne-a software testing firm in which the majority of employees have a diagnosis on the autism spectrum. This firm appears to have special hiring working practices and a supportive, flexible organizational climate that effectively captures the benefits arising from its employees' high attention to detail, excellent memory, and ability to concentrate and work systematically. As the founder of Specialisterne, Thorkil Sonne, explains it,

"We believe in a model of human relations management that focuses on identifying market opportunities that match the talent of the personnel - not force-fitting employees into a defined culture or market niche. (...) It is a paradigm that demands entrepreneurial creativity of the manager to carve out space in the market that welcomes the talents of the 
employee that might otherwise be deemed unusable in a traditional company or industry.” (Wareham \& Sonne, 2008, 26-27) ${ }^{2}$

Returning to our focus on entrepreneurs with a mental disorder, they are likely to create alternate mechanisms for achieving collaboration and coordination (e.g., Klotz et al., 2014) or are likely to keep their ventures small to minimize the need for creating such alternate skills. Indeed, individuals with mental disorders often develop unique organizing capabilities that accommodate their specific weaknesses well. For example, Logan (2009) found that entrepreneurs with dyslexia used compensatory strategies developed early in their lives to successfully delegate, communicate with, and motivate employees. They learned at an early age to ask others for help with tasks they found difficult and to trust others, something that helped them as entrepreneurs when they needed to delegate when their growing ventures. Studying these entrepreneurs at the tail may reveal insights into novel ways of organizing entrepreneurial activity and inform entrepreneurship and organization theory alike. For those with mental disorders who choose to manage their symptoms by keeping their businesses small, these businesses likely represent an under-utilized resource in the economy and/or the extreme case of the founder's dilemma (Wasserman, 2008). That is, the entrepreneur with a mental disorder can maintain control of his or her venture (be the king/queen), or they can grow the venture (be rich), requiring them to develop special ways of coordinating their workforce, but they will find it difficult to do both. Understanding the aspects of the entrepreneurial process that benefit most from a mental disorder and those aspects that are constrained or diminished most by a mental disorder is going to be key to thinking about whether the entrepreneur wants to be richeffectively coordinating his or her large HR base—or the king/queen—controlling his or her small empire (see Wasserman, 2008).

\section{Research Opportunity 5: Mental Disorders and Entrepreneurial Social Ties}

\footnotetext{
${ }^{2}$ Entrepreneurial creativity refers to "the capacity to identify novel and useful solutions to problems in the form of new products or services” (Perry-Smith \& Coff, 2011: 248).
} 
A large body of literature has emphasized the importance of social ties for entrepreneurs, in particular emphasizing their important role in providing access to essential resources for the foundation and development of new ventures (e.g., Florin, Lubatkin \& Schulze, 2003; Maurer \& Ebers, 2006). However, social integration in a strong network can also provide people with a sense of purpose, belonging, and security as well as recognition of self-worth (Thoits, 2011). In turn, functional aspects of social relationships (e.g., perceived support) are thought to buffer the effects of stress by enhancing an individual's coping abilities (Kawachi \& Berkman, 2001). These benefits are especially important for people with mental disorders, such as those with depression, who struggle to find a sense of purpose and control and face impairments in terms of social functioning (Hessels et al., 2017). Thus, by providing behavioral guidance and confidence in one's ability to cope in the face of new challenges, strong social ties inside and outside the venture might be an even more important prerequisite for entrepreneurs with mental disorders than for those in the middle of the distribution, as such ties enhance their productivity and venture performance.

The need to depend on others might also lead to the development of a unique capability to build strong social ties, which appears to be useful for all individuals creating and growing a business. For example, Miller and Le Breton Miller (2017) reported that some individuals with dyslexia have been forced to work with and rely on other people to accomplish tasks; for example, these other people might help with parsing reading materials (Logan \& Martin, 2012). Exploring the nature of these relationship-building capabilities and the ways they emerge (perhaps early in life [Logan, 2009; Miller \& Le Breton Miller, 2017]) and understanding how and when they can best be used by entrepreneurs with mental disorders will likely facilitate new theorizing on the role of strong social ties in entrepreneurship. It could be that individuals with mental disorders who must rely on building strong ties may develop a broad repertoire of social competences. Yet, we need to know what they are, how they are developed (e.g., by levering strengths in other competences arising from their mental disorders), and which are most effective. Individuals with mental disorders may be able to stimulate prosocial motivation and 
behaviors in others - we need to know how to bring out the "prosocial” in others and to what effect for the helper, the helped, the relationship, and the venture. Finally, these individuals may engage in prosocial behaviors themselves to reciprocate others' help, generate help in the future, and/or "pay it forward.” These are all important and interesting issues to be explored in future research.

Further, as people with mental disorders are often stigmatized, entrepreneurs might try to hide their mental disorders from others and/or build networks with those facing similar challenges (also consistent with the similarity principle [Bryne, 1971] and homophily [McPherson, Smith-Lovin, \& Cook, 2001]). Some entrepreneurs with mental disorders have likely found ways to circumvent stigmatization, such as using impression management, to maintain and build social ties. Although it is interesting to explore the nature of these impression-management strategies and determine whether they are transferable to other aspects of the entrepreneurial task (e.g., managing stakeholders’ impressions given negative performance feedback), it is also important that future research explores the implications of entrepreneurs' effectively hiding their mental disorders. We know that concealing stigmas can create additional strain and psychological challenges for the focal individual (Pachankis, 2007), and by hiding a disorder, an individual is likely to obtain less help in dealing with its symptoms (Schulze, 2007). Both of these situations can exacerbate the negative consequences of the mental disorder and further deteriorate well-being. Perhaps entrepreneurs who are less effective at impression management benefit more in terms of improved mental health in the long run.

For individuals with mental disorders, networking with others who have the same mental disorder or another form of stigmatization is likely difficult because appropriate partners are rare, difficult to identify, and may use impression management to avoid such connections. However, such networks may provide an important source of trusting relationships in which individuals can openly and honestly share information about the nature and effects of mental disorders in entrepreneurship as well as discuss tools, strategies, and routines that are most effective for capitalizing on the strengths and minimizing the weaknesses of particular mental disorders. 
Therefore, it is important for future research to explore to what extent entrepreneurs with mental disorders form new relationships and build networks (including whether they do so at all), how and with whom they form these relationships (i.e., network structure), and the nature of the resources that flow through these network structures. In addition, future research should compare and contrast these network functions and flows with those of other entrepreneurs (i.e., entrepreneurs without mental disorders or entrepreneurs with different mental disorders) and with those of other individuals with mental disorders (e.g., those in different forms of selfemployment, traditional employment, or even unemployment). Research along these lines has considerable potential to make important contributions to the literatures on entrepreneurship, social networks, and social ties.

\section{Research Opportunity 6: The Entrepreneurial Process’ Impact on Mental Disorders}

While is seems promising to study how mental disorders impact the entrepreneurial process, studying how the entrepreneurial process influences disorder symptoms is also important. For example, Lasky et al. (2016) found that work environments that are stimulating, challenging, busy, fast paced, intrinsically motivating, full of novelty, and requiring multitasking diminished the symptoms of people diagnosed with ADHD. Such work conditions resonate with entrepreneurship. Further, the entrepreneurial process can generate positive emotions (Fredrickson, 1998) and many entrepreneurs are highly passionate about specific aspects of the entrepreneurial process (but not necessarily all aspects), resulting in positive emotional experiences (Cardon et al., 2009; Cardon, Foo, Shepherd, \& Wiklund, 2012). For example, it has been shown that engaging in entrepreneurial behaviors such as developing new products or building new business networks can be seen as a means for inducing positive emotions (Kato \& Wiklund, 2011), and that entrepreneurial action leads to passion (Gielnik et al., 2015), rather than passion promoting entrepreneurial action (Cardon, Wincent, Singh, \& Drnovsek, 2009). These positive emotions generated through engagement in entrepreneurial tasks may also diminish symptoms of a mental disorder. More research is needed on how entrepreneurship generates positive emotions (especially in those with specific mental disorders) and how these 
positive emotions minimize the effects of a mental disorder or minimize the mental disorder itself. Interestingly, the relationship between emotions and disorders may introduce a paradox: a mental disability may enable an individual to successfully complete a challenging task (e.g., through heightened creativity), and the positive emotions generated from completing the challenging task may reduce the mental disorder that is critical to success. The question then becomes how can we have the best of both worlds: how does one keep the benefits of the mental disorder without the negative outcomes that are also typically bundled with it?

Over and above the "undoing" effect of positive emotions, entrepreneurial activity may also directly reduce negative emotions (Patzelt \& Shepherd, 2011; Shepherd \& Patzelt, 2015) by allowing people to avoid (or minimize exposure to) onerous tasks and situations. This is likely highly advantageous for entrepreneurs with mental disorders. For example, those suffering from social anxiety disorders can minimize their contact with strangers by using well-known partners to manage new external relationships for the venture. However, where do these "well-known partners” come from - they must have been new at some stage. Perhaps running one's own venture and having greater control of the situation helps entrepreneurs manage their anxiety over new social situations, thus diminishing their level of negative emotions. That is, perhaps entrepreneurial tasks provide some level of control over social exchanges such that there is less "new" in the exchange to generate anxiety (e.g., the meeting takes place in the entrepreneur's office, the stakeholders already likely know a great deal about the entrepreneur's business and the entrepreneur him- or herself, new stakeholders' motivations are likely known to or relatively easily anticipated by the entrepreneur, the points for discussion are likely known or can be anticipated, and so on). Over time, such exchanges may either desensitize these individuals to new social exchanges or enable them to build social skills, both of which are likely to reduce the severity of their mental disorder. Exploring to what extent entrepreneurship can be a "therapeutic" career path for those with mental disorders has the potential to substantially increase our understanding of the benefits of entrepreneurship for individuals, specifically those with mental disorders. For example, by engaging in entrepreneurial tasks, individuals may 
progress from the left tail of mental health toward the center of the distribution, and perhaps those in the center progress further to the right—-that is, to even greater mental health.

On the downside, however, entrepreneurship can trigger negative emotions that exacerbate or lead to mental disorders. For example, negative emotions can arise from entrepreneurs' unpleasant social interactions such as those with state officials who employ power rituals when dealing with entrepreneurs' requests (Doern \& Goss, 2014), or from the risk entrepreneurs perceive to be associated with the exploitation of an opportunity (Foo, 2009), and these feelings can further exacerbate some symptoms of mental disorders. Moreover, failure of their entrepreneurial endeavor might have disastrous effects on people with some types of mental disorders. Entrepreneurial failure often causes feelings of loss and negative emotions (i.e., grief) (Shepherd, 2003; Shepherd et al., 2016), and these feelings can further exacerbate some symptoms of mental disorders. Negative life events such as business failure are known antecedents of depression (Abramson et al., 1989) and substantially prolong the recovery from bipolar disorder (Johnson \& Miller, 1997). For individuals at the tail of the distribution, the consequences of business failure appear more dramatic than suggested by current "entrepreneurial grief" studies, and failure may actually move them even more toward the distribution's tail. This creates somewhat of a paradox in that people with mental disorders (relative to those without mental disorders) may benefit more from a successful entrepreneurial endeavor but may suffer more from a failed entrepreneurial endeavor-a greater dispersion of psychological outcomes from undertaking an entrepreneurial endeavor.

The tools that help individuals emotionally recover and learn from their failure experiences (e.g., an oscillation orientation [Shepherd, 2003; Shepherd et al., 2011]) — that is, tools that truncate the failure tail of the outcome distribution-may not be highly applicable to people with specific mental disorders. This suggests that entrepreneurs with mental disorders develop different tools for coping with grief (we need to gain a deeper understanding of what they are), or take the risk (we need to understand how entrepreneurs with mental disorders attend to, interpret, and act in highly uncertain environments; it could be that they decide to take the 
plunge or that they are not fully aware of what a failure will mean to them). Such research is important because it can eventually help reduce the suffering of individuals with mental disorders by hopefully maximizing the benefits of engaging in entrepreneurial action while minimizing the costs associated with failure-a frequently occurring outcome of entrepreneurial action (Shepherd, 2003; Shepherd et al., 2011).

However, there are potentially wider implications. By understanding, for example, why some entrepreneurs with a particular mental disorder are able to emotionally recover from failure and learn from the experience, the lessons learned may be transferable to entrepreneurs without mental disorders but importantly may be transferable to individuals with mental disorders who may face failure in other important life tasks (i.e., non-entrepreneurial tasks, such as in school, employment, and romantic relationships). Much research is needed into this topic.

Furthermore, studies have established that, on average, entrepreneurs work more (Eden, 1975; Bird, 1988; Harris et al., 1999) but earn less than employed people (Hamilton, 2000; Blanchflower \& Shadforth, 2007; Shane, 2008; Astebro, Chen \& Thompson, 2011), which could adversely impact mental health. High psychological work demands (i.e., excessive workload and extreme time demands) are positively associated with both the entrepreneurial process and higher risk of depression and anxiety (Melchior et al., 2007). Studies (for an overview, see Rauch et al., 2017; Stephan, 2018) point to both sides of the entrepreneurship-stress relationship: some studies indicate that entrepreneurship decreases stress (e.g., through job design), and others say it raises stress (e.g., through long work hours). Both of these lines of thinking can be right, just not for all people and not for all entrepreneurial ventures and not for all stages of the entrepreneurial lifecycle. That is, we need to gain a deeper understanding of how different aspects of the entrepreneurial process lead to stress for some and stress release for others and why, when, and with what effects.

An important step in such research is understanding differences in stressors and stress reactions for people with mental disorders vis-à-vis those without mental disorders and across the various mental disorders. For example, for entrepreneurs with bipolar disorder in hypomanic 
episodes, long working hours are unlikely to cause stress and may even reduce it. By exploring potential stressors and why they do not lead to stress in certain individuals may also provide important insights into resources and capabilities that can build resilience. Alternatively, stress reactions may have positive performance implications for some entrepreneurs with mental disorders by activating and effectively channeling their creativity. Such counterintuitive findings would not only be interesting but can contribute to resolving the empirical heterogeneity regarding outcomes of stress in entrepreneurship.

In this regard, taking account of environmental contingencies may be critical as some entrepreneurs operate in complex and dynamic high-tech business environments, which often demand ambidextrous entrepreneurial behavior that is both aligned and adaptable (Rauch et al., 2017). While the sensation seeking of entrepreneurs with ADHD (Wiklund et al., 2017b) may enable them to thrive in dynamic environments on the basis of excitement, high activation, and positive stress, they may experience performance-reducing boredom and distress in more stable, slowly changing contexts. Similarly, the characteristics of the entrepreneurial lifecycle need to be considered when examining the interplay of mental disorders, stressors, and stress reactions, or as Cardon and Patel (2015, p. 405) put it, the "entrepreneurial process is like a rollercoaster that one is trying to control while on it, suggesting that there are periods of high pressure and stress, but also periods that are slower and more stable and predictable.” By focusing research on mental disorders, we can (hopefully) more readily identify the nature of these stress-inducing and stress-releasing relationships as well as disentangle the outcomes of eustress and distress, thereby pushing the boundaries of existing theories on entrepreneurship and stress.

\section{Research Opportunity 7: Work-Life Balance, Entrepreneurship, and Mental Disorders}

Mental disorders influence all spheres of life, and problems in one sphere tend to spill over into other spheres (as do opportunities). For example, people with mental disorders, such as ADHD and/or autism, tend to be more vulnerable and react more strongly to stress in the workplace, which can have substantial implications for their private lives (Lerner, 2017). As such, it seems particularly important to consider the interplay between the individual and the 
wider context when studying entrepreneurship and mental disorders. Specifically, scholars have shown increased interest in work-life balance for entrepreneurs (e.g., Jennings \& McDougald, 2007; Eddleston \& Powell, 2012; Powell \& Eddleston, 2013; Hsu et al., 2017), and studies of work-life balance among entrepreneurs with mental disorders are likely to be highly valuable. For example, is it easier or harder for people with mental disorders to find a productive work-life balance in an entrepreneurial career than in other lines of work?

On the one hand, entrepreneurs have the autonomy to choose and design their work tasks and performance benchmarks in ways that suit their personal needs (Miner, Smith \& Bracker, 1989), including their non-work-related personal needs. Thus, an entrepreneurial career could potentially offer unique possibilities for people with mental disorders to achieve work-life balance. On the other hand, many people with mental disorders have problems with selfregulation (Corbisiero et al., 2017), potentially making them addicted to entrepreneurship (Spivack \& McKelvie, 2017). Thus, the autonomy of entrepreneurship may actually entice them to become overly engaged and absorbed by their business, work too hard, and experience poor work-life balance and even burnout as an outcome of chronic stress. Future research can explore how entrepreneurs with mental disorders are able to best achieve work-life balance and, importantly, what work-life balance means to them (which could be a very different "balance” for an entrepreneur without a mental disorder or for entrepreneurs with different mental disorders). There is an extensive literature on workplace adaptations or interventions to accommodate various disabilities (e.g., Schonstein \& Verbeek, 2006; Corbiére et al., 2009), which may form a basis from which future research can begin to investigate the adaptations entrepreneurs with mental disorders make to their own workplaces. Alternatively, research that inductively generates theories on how entrepreneurs with different mental disorders are able to achieve work-life balance may contribute to the workplace disability literature and can have important practical implications (e.g., workplaces may adopt some of the crafted workplaces of entrepreneurs with mental disabilities that help them achieve good work-life balance).

\section{Research Opportunity 8: Loved Ones, Entrepreneurship, and Mental Disorders}


It is not only the individual with the mental disorder who is impacted by symptoms and dysfunctions, but loved ones often suffer, too (Eakin et al., 2004). Loved ones are likely an important information source to gain a deeper understanding of the functioning of mental disorders in entrepreneurship. Indeed, there is an extensive literature on how families deal with living with a loved one diagnosed with a mental disorder (e.g., Pakenham, Samios \& Sofronoff, 2005; Renty \& Roeyers, 2007). Social support and effective coping strategies are essential for functioning in a relationship with an individual who has a mental disorder (Renty \& Roeyers, 2007). Interestingly, although the family business literature has highlighted how the family and work spheres are inter-related for entrepreneurs and their families (Aldrich \& Cliff, 2003; Jennings \& McDougald, 2007) and entrepreneurship scholars have studied coping with stressful events (e.g., Shepherd, 2003; Jenkins, Wiklund, \& Brundin, 2014), few (if any) studies have taken the perspective of the spouse, examining the implications of being in a romantic long-term relationship with an entrepreneur (in this case, an entrepreneur with a mental disorder). Living with an entrepreneur is generally a stressful experience for the entrepreneur's partner because of uncertainty regarding income levels and the future survival of the business spreading to the family sphere, with the resulting family dynamics bouncing back to the business sphere. This stress is likely exacerbated when the entrepreneur also has a mental disorder. Future research would benefit from studying the interplay of personal-, business-, and family-related consequences of being in a romantic long-term relationship with an entrepreneur with a mental disorder, for example, using the double ABCX model of adjustment and adaptation (McCubbin \& Patterson, 1983).

In addition, recent case studies of entrepreneurs with mental disorders suggest that their spouses play important roles in their businesses despite not having a formal role (Wiklund, Patzelt \& Dimov, 2016). Challenges for entrepreneurs with mental disorders are similar in the family and the business spheres, and spouses seem to compensate for the problems faced by entrepreneurs with mental disorders in similar ways in both spheres (Wiklund et al., 2016). For example, people with ADHD often have problems focusing and seeing things through to fruition 
before jumping on to something new. Spouses can assist in providing more focus both in private and business-related matters.

Furthermore, the relationship between work stress and impaired mental health is attenuated for individuals who have a more satisfying, high-quality family life (Barnett et al., 1992). Thus, future research would benefit from studying the influence that family relationships, especially spousal relationships, have on the performance of entrepreneurs with mental disorders and their businesses. Based on this and the general finding that spouses' personalities influence job success (Solomon \& Jackson, 2014), we believe that such future research on the informal contributions of spouses will be valuable to our understanding of entrepreneurship and families, especially family businesses.

\section{Research Opportunity 9: Clinical Approaches to Entrepreneurship}

Although a dominant force in the field of psychiatry, the study of mental disorders and the adoption of clinical approaches from neuroscience are virtually absent in entrepreneurship research, yet they have the potential to make a strong contribution to our understanding of entrepreneurial phenomena (Nicolaou \& Shane, 2014). For example, one important insight from psychiatry is the notion of dual-model processing, the idea that two different decision systems (i.e., hot and cool) are involved in decision making when facing uncertainty (e.g., Wood \& Bechara, 2014). The "hot" system is impulsive, rapid, intuitive, and emotional, and the "cool" system is slow, analytical, and reflective (Evans, 2008; Kahneman, 2011; Wood \& Bechara, 2014). In entrepreneurship, with its fundamental premise of action under uncertainty (McMullen \& Shepherd, 2006), the joint consideration of these hot and cool systems may be of particular value (Shepherd, 2015; Wiklund et al., 2017b)—even more so when we consider that several mental disorders are characterized by over-activation of the hot impulsive system (e.g., learning disorders, ADHD, and bipolar disorder).

It seems that society highly values the cool system with its slow, analytical, and reflective elements and perhaps maligns the hot impulsive system (e.g., it is not good to be labeled a "hot head”). By studying entrepreneurs with mental disorders that emphasize the hot impulsive 
system, we can gain a better understanding of when (situations, tasks, events, and so on) to effectively apply some heat. For entrepreneurs with certain mental disorders, we hope that we can shed light on the situations in which the hot impulsive system is well suited to them so that these individuals can self-select into business environments and focus on tasks that reward intuition. For example, in highly dynamic environments, such as the high-tech industry, and especially in the course of exploring innovation, it is likely more important to act quickly and make sense of those actions to move forward (Brown \& Eisenhardt, 1997; McGrath, 1999), which is consistent with sensemaking (Weick, 1995), rather than use the slower cool system.

As we gain a deeper understanding of when the hot impulsive system is most effective (e.g., by studying entrepreneurs with mental disorders characterized by an over-activation of the impulsive system), we may be able to use this information to help individuals without mental disorders engage their hot impulsive systems in relevant situations. The irony is that while the focus has been on teaching people at the tail of the hot impulsive system to become more cool (we suspect because of an emphasis on problem solving based on known information), the same level of energy has not been applied to teaching those at the tail of the cool slow system to become more hot. Future research will add substantially to this conversation.

\section{Research Opportunity 10: Examining the Tails of the Distribution}

Most human characteristics, traits, and behaviors tend to generate normal distributions, which is reflected in the psychological theories purporting to explain them. Extreme cases are captured in specific psychological theories of abnormality. With a few exceptions, psychological research in entrepreneurship has applied theories and empirical research methods that focus (implicitly or explicitly) on mean tendencies. That is, less scholarly attention has been paid to entrepreneurs at the tails of the distribution. However, these tails, or "extreme cases," deserve more attention by entrepreneurship scholars because most entrepreneurial phenomena do not follow normal distributions but rather power distributions where the few cases at the tails make extraordinary contributions to important entrepreneurial outcomes. For example, Crawford et al. (2015) illustrate that human capital is power law distributed, with "a minority of individuals who 
perform at a level that is many orders of magnitude above the rest” (p. 5). This observation is consistent with the above mentioned anecdotal evidence suggesting that some people with mental disorders have achieved extraordinary entrepreneurial success and that they view their mental disorder as an asset rather than a liability in achieving this success. Similarly, given the need to rely on others for effective entrepreneurial functioning, perhaps those with mental disorders may belong to the minority of entrepreneurs who possess extraordinarily large networks that account for the power distribution of social ties among the entrepreneurial population (Crawford et al., 2015). As a final example, Crawford et al. (2015) find that the number of entrepreneurial activities and time entrepreneurs invest in their ventures is power distributed. Some mental disorders such as ADHD are associated with extraordinarily high activity levels (Schecklmann et al., 2008) and might provide an explanation for this distribution of entrepreneurial effort. Scholars might find the framework provided by Crawford et al. (2015) as a useful starting point for exploring how mental disorders explain the power distribution of many important variables in entrepreneurship theory.

Moreover, the study of extreme cases is also important in generating new theoretical insights because interesting phenomena are more salient, and it is possible to select polar cases with extreme values along important variables to gain a deeper understanding of how these variables influence phenomena of interest (Eisenhardt, 1989; Yin, 1994). For example, it would be interesting to study entrepreneurship among people with bipolar disorder (Johnson et al., 2018) and compare their actions and outcomes during their manic periods with their actions and outcomes during their depressed episodes. We acknowledge that during the depressed episodes, ventures might actually disappear, which makes them challenging to identify. Yet, such a setting would constitute a promising within-subject research design allowing the study of how important psychological variables, such as mood, passion, optimism, and drive, influence entrepreneurship. Both detailed case studies and broadly based surveys are foreseeable. In this regard, studying those extreme cases through interviews and surveys could be complemented with novel technology. 
Given the central role of mobile, social, and wearable computing in people's lives, researchers may use mobile systems in conjunction with experience sampling to overcome the biases associated with retrospective reports (Morris \& Aguilera, 2012) and develop a deeper understanding of the situational advantages and challenges associated with mental disorders in entrepreneurship. Specifically, recent developments in mobile applications and sensor technology not only enhance clinical management and early intervention through access to realtime patient data but also provide a tool for research. These sensor technologies allow for the generation of ultra-dense large sets of individualized data that-when matched, for example, with dynamic pattern analysis tools characterizing spaces of changing variables (Picard, 2009) will lead to a richer understanding of entrepreneurs with mental disorders. For example, there are mobile apps that focus on mood disorders such as a bipolar tracker, allowing users to input and keep track of subjective mood ratings, hours of sleep, anxiety levels, and medication use. These apps also generate reports that can be sent to family members, caregivers, clinicians, and researchers. Similar apps have been developed for developmental, cognitive, psychotic and substance-related disorders (Luxton et al., 2011). By additionally using sensors such as gyroscopes, accelerometers, microphones and cameras (all standard in most smartphones), it will be possible to continuously collect data as a basis for nuanced insights into entrepreneurs' thoughts, feelings, and behaviors. For example, observing subtle changes in sleep and activity patterns could enable the detection of early warning signs of mania, helping both the entrepreneur "manage" his or her mental disorders by adjusting treatment, and the researcher to better understand potential changes in the engagement and performance of specific activities, such as for example, opportunity identification and evaluation. However, while the growing integration of mobile technology into mental disorder research has been evidenced by clinical trials of mobile interventions for depression (Arean et al., 2016), schizophrenia (Depp et al., 2010) and borderline personality disorder (Rizvi et al., 2011), these methodological innovations are largely absent in entrepreneurship research. 
Similarly, another promising line of research involves studying entrepreneurs with specific mental disorders and comparing their behavior during periods in which they take medication for their conditions with periods in which they do not. This type of within-subject research design will allow researchers to isolate how factors associated with a disorder influence entrepreneurial behavior and outcomes. Such studies have been carried out in other fields. For example, the whole population of Swedes diagnosed with ADHD has been examined using this type of research approach. Scholars gathered information on more than 25,000 patients diagnosed with ADHD, their pharmacologic treatment, and subsequent criminal convictions in Sweden from 2006 to 2009. They found a reduction of 32\% in the criminality rate for men and $41 \%$ for women among patients receiving ADHD medication compared to non-medication periods (Lichtenstein et al., 2012). Using similar data, another study showed that men with ADHD reduced their involvement in serious traffic accidents by 58\% when taking ADHD medication compared to non-medication periods (Chang et al., 2014). Thus, ADHD medication seems to have a profound influence on important outcomes. With regard to the entrepreneurship context, medication may downplay the disorder's advantages, such as creativity, shifting those with mental disorders to the center of a normal distribution. Here, longitudinal research designs that take the use and discontinuation of medication into account are needed to clearly understand the relationships between mental disorders and entrepreneurship.

More generally, there is likely great opportunity to piggy-back on the extensive epidemiological studies focused on mental disorders. For example, databases involving the whole Swedish population diagnosed with serious mental disorders (used in Kyaga et al., 2011) or ADHD specifically (e.g., Lichtenstein et al., 2012) can be linked to other registers containing information about labor market activities, such as entrepreneurial endeavors or unemployment. In addition, panel studies of health in general, or of specific mental disorders, are conducted around the world. It should be possible to include aspects of entrepreneurship in such studies, such as whether and when these people entered self-employment or created a new organization.

\section{CONCLUSION}


Entrepreneurship is predicated on one's ability to identify opportunities that others cannot, which highlights the importance of entrepreneurs' being different. The extent to which mental disorders provide unique abilities and perspectives that are particularly valuable in entrepreneurship remains an open question, but there are indications that certain mental disorders are over-represented among highly successful entrepreneurs. While there are good reasons from the perspective of those with a mental disorder to further explore the role of mental disorders in entrepreneurship, there are also theoretical incentives for exploring these relationships. There is a growing body of evidence on how certain personality characteristics are associated with entrepreneurial affect, cognition, and action, yet with a clinical approach, psychological characteristics associated with pathology provide an alternative focus. To the extent that such "negative" or "excessive" traits and characteristics are associated with common entrepreneurial outcomes, such as entry into self-employment, innovation, or new venture performance, there is an opportunity to push the boundaries of existing theories and provide new insights, including the notion of equifinality in entrepreneurial endeavors and plurality in entrepreneurial logics for action.

From a practical viewpoint, researching mental health with its far-reaching human, financial, and societal implications is of utmost importance. Given the problems of those suffering from mental disorders in the conventional workplace, entrepreneurship likely provides an important alternative career path for these individuals to earn a living, reduce suffering, and live a "good" life. For example, a study by Haynie and Shepherd (2011) showed that entrepreneurship education and practice helped military veterans traumatized by combat to overcome psychological constraints and move on with their lives. Further, Patzelt, Williams, and Shepherd (2014) found that recognizing and developing entrepreneurial opportunities as part of an entrepreneurship program in the prison context helped inmates change their mental frames such that they gained more positive attitudes toward their own (entrepreneurial) competencies, their situation in prison, and others in their social environment. Nonetheless, given that the entrepreneurial outcomes of those suffering from mental disorders have not been rigorously 
investigated, it is of critical importance that future research explores the role of mental disorders in entrepreneurship to inform clinicians about the value of an entrepreneurial career for patients with certain mental disorders, a career in which their uniqueness may provide an advantage and the process may improve their mental health. 


\section{References}

Abramson, L. Y., Metalsky, G. I., \& Alloy, L. B. (1989). Hopelessness depression: A theorybased subtype of depression. Psychological Review, 96(2), 358.

Aldrich, H. E., \& Cliff, J. E. (2003). The pervasive effects of family on entrepreneurship: Toward a family embeddedness perspective. Journal of Business Venturing, 18(5), 573-596.

Aldrich, H. E., \& Fiol, C. M. (1994). Fools rush in? The institutional context of industry creation. Academy of Management Review, 19(4), 645-670.

APA (2000). Diagnostic and statistical manual of mental disorders, (4th ed., text revision). Washington, DC: American Psychiatric Association.

American Psychiatric Association (2013). Diagnostic and statistical manual of mental disorders (DSM-5). American Psychiatric Pub.

Anthsel, K. (2017). Attention deficit / hyperactivity disorder (ADHD) and entrepreneurship. Academy of Management Perspectives, doi:10.5465/amp.2016.0144.

Archer, D. (2014). ADHD: The entrepreneur's superpower. Forbes. Retrieved from http://www.forbes.com/sites/dalearcher/2014/05/14/adhd-the-entrepreneurssuperpower/\#3bfba1997063.

Arean, P. A., Hallgren, K. A., Jordan, J. T., Gazzaley, A., Atkins, D. C., Heagerty, P. J., \& Anguera, J. A. (2016). The Use and Effectiveness of Mobile Apps for Depression: Results From a Fully Remote Clinical Trial. Journal of Medical Internet Research, 18(12), e330.

Åstebro, T., Chen, J., \& Thompson, P. (2011). Stars and misfits: Self-employment and labor market frictions. Management Science, 57(11), 1999-2017.

Back, M. D., Schmukle, S. C., \& Egloff, B. (2010). Why are narcissists so charming at first sight? Decoding the narcissism-popularity link at zero acquaintance. Journal of Personality and Social Psychology, 98(1), 132.

Barnett, R. C., Marshall, N. L., \& Pleck, J. H. (1992). Men's multiple roles and their relationship to men's psychological distress. Journal of Marriage and the Family, 54, 358-367.

Baron, R. A. (2000). Psychological perspectives on entrepreneurship: Cognitive and social factors in entrepreneurs' success. Current Directions in Psychological Science, 9(1), 15-18.

Baron, R. A. (2008). The role of affect in the entrepreneurial process. Academy of Management Review, 33(2), 328-340.

Baron, R. A. (2010). Job design and entrepreneurship: Why closer connections= mutual gains. Journal of Organizational Behavior, 31(2-3), 370-378.

Baron, R. A., \& Tang, J. (2011). The role of entrepreneurs in firm-level innovation: Joint effects of positive affect, creativity, and environmental dynamism. Journal of Business Venturing, 26, 49-60.

Baron, R. A., Franklin, R. J., \& Hmieleski, K. M. (2016). Why Entrepreneurs Often Experience Low, Not High, Levels of Stress The Joint Effects of Selection and Psychological Capital. Journal of Management, 42(3), 742- 768.

Baron-Cohen, S., Ashwin, E., Ashwin, C., Tavassoli, T., \& Chakrabarti, B. (2009). Talent in autism: hyper-systemizing, hyper-attention to detail and sensory hypersensitivity. Philosophical Transactions of the Royal Society of London B: Biological Sciences, 364(1522), 1377-1383.

Becker, G. S. (1976). Human capital: A theoretical and empirical analysis, with special reference to education. University of Chicago Press.

Bird, B. (1988). Implementing entrepreneurial ideas: The case for intention. Academy of Management Review, 13(3), 442-453. 
Blanchflower, D. G., \& Shadforth, C. (2007). Entrepreneurship in the UK. Foundations and Trends in Entrepreneurship, 3(4), 257-364.

Blume, B. D., \& Covin, J. G. (2011). Attributions to intuition in the venture founding process: Do entrepreneurs actually use intuition or just say that they do?. Journal of Business Venturing, 26(1), 137-151.

Bogan, V., Fertig, A., \& Just, D. (2013). Self-Employment and Mental Health. Available at SSRN 2259765.

Boyd, D. P., \& Gumpert, D. E. (1983). Coping with entrepreneurial stress. Harvard Business Review, 61(2), 44-64.

Brown, S. L., \& Eisenhardt, K. M. (1997). The art of continuous change: Linking complexity theory and time-paced evolution in relentlessly shifting organizations. Administrative Science Quarterly, 1-34.

Byrne, D. (1971). The attraction paradigm. New York: Academic Press.

Byrne, O., \& Shepherd, D. A. (2015). Different strokes for different folks: Entrepreneurial narratives of emotion, cognition, and making sense of business failure. Entrepreneurship Theory and Practice, 39(2), 375-405.

Campbell, W. K., Hoffman, B. J., Campbell, S. M., \& Marchisio, G. (2011). Narcissism in organizational contexts. Human Resource Management Review, 21(4), 268-284.

Cardon, M. S., \& Patel, P. C. (2015). Is stress worth it? Stress-related health and wealth tradeoffs for entrepreneurs. Applied Psychology, 64(2), 379-420.

Cardon, M. S., Foo, M. D., Shepherd, D., \& Wiklund, J. (2012). Exploring the heart: Entrepreneurial emotion is a hot topic. Entrepreneurship Theory and Practice, 36(1), 1-10.

Cardon, M. S., Wincent, J., Singh, J., \& Drnovsek, M. (2009). The nature and experience of entrepreneurial passion. Academy of Management Review, 34(3), 511-532.

Chang, Z., Lichtenstein, P., D’Onofrio, B. M., Sjölander, A., \& Larsson, H. (2014). Serious transport accidents in adults with attention-deficit/hyperactivity disorder and the effect of medication: a population-based study. JAMA Psychiatry, 71(3), 319-325.

Chen, X. P., Yao, X., \& Kotha, S. (2009). Entrepreneur passion and preparedness in business plan presentations: a persuasion analysis of venture capitalists' funding decisions. Academy of Management Journal, 52(1), 199-214.

Christie, R., \& Geis, F. L. (1970). Studies in machiavellianism. London: Academic Press.

Corbière, M., Shen, J., Rouleau, M., \& Dewa, C. S. (2009). A systematic review of preventive interventions regarding mental health issues in organizations. Work, 33(1), 81-116.

Corbisiero, S., Mörstedt, B., Bitto, H., \& Stieglitz, R. D. (2017). Emotional Dysregulation in Adults With Attention-Deficit/Hyperactivity Disorder-Validity, Predictability, Severity, and Comorbidity. Journal of Clinical Psychology, 73(1), 99-112.

Corrigan, P. W., Markowitz, F. E., \& Watson, A. C. (2004). Structural levels of mental illness stigma and discrimination. Schizophrenia Bulletin, 30, 481-491.

Crawford, G. C., Aguinis, H., Lichtenstein, B., Davidsson, P., \& McKelvey, B. (2015). Power law distributions in entrepreneurship: Implications for theory and research. Journal of Business Venturing, 30(5), 696-713.

Dahl, M. S., Nielsen, J., \& Mojtabai, R. (2010). The effects of becoming an entrepreneur on the use of psychotropics among entrepreneurs and their spouses. Scandinavian Journal of Social Medicine, 38(8), 857-863.

Dane, E., \& Pratt, M. G. (2007). Exploring intuition and its role in managerial decision making. Academy of Management Review, 32(1), 33-54.

D'Angelo, B., \& Wierzbicki, M. (2003). Relations of daily hassles with both anxious and depressed mood in students. Psychological Reports, 92(2), 416-418. 
Davis, G. F. (2015). Editorial essay: what is organizational research for?. Administrative Science Quarterly, 60(2), 179-188.

Depp C.A., Mausbach, B., Granholm, E., Cardenas, V., Ben-Zeev, D., Patterson, T.L., \& Jeste, D.V. (2010). Mobile interventions for severe mental illness: Design and preliminary data from three approaches. Journal of Nervous and Mental Disease, 198, 715-721.

Doern, R., \& Goss, D. (2014). The Role of Negative Emotions in the Social Processes of Entrepreneurship: Power Rituals and Shame-Related Appeasement Behaviors. Entrepreneurship Theory and Practice, 38(4), 863-890.

Douglas, E. J., \& Shepherd, D. A. (2000). Entrepreneurship as a utility maximizing response. Journal of Business Venturing, 15(3), 231-251.

Douglas, E. J., \& Shepherd, D. A. (2002). Self-employment as a career choice: attitudes, entrepreneurial intentions, and utility maximization. Entrepreneurship Theory and Practice, 26(3), 81-90.

Eakin, L., Minde, K., Hechtman, L., Ochs, E., Krane, E., Bouffard, R., ... \& Looper, K. (2004). The marital and family functioning of adults with ADHD and their spouses. Journal of Attention Disorders, 8(1), 1-10.

Eckblad, M., \& Chapman, L. J. (1986). Development and validation of a scale for hypomanic personality. Journal of Abnormal Psychology, 95(3), 214-222.

Eddleston, K. A., \& Powell, G. N. (2012). Nurturing entrepreneurs' work-family balance: A gendered perspective. Entrepreneurship Theory and Practice, 36(3), 513-541.

Eden, D. (1975). Organizational membership vs self-employment: Another blow to the American dream. Organizational Behavior and Human Performance, 13(1), 79-94.

Eden, G. F., VanMeter, J. W., Rumsey, J. M., \& Maisog, J. M. (1996). Abnormal processing of visual motion in dyslexia revealed by functional brain imaging. Nature, 382(6586), 66-69.

Eisenhardt, K. M. (1989). Building theories from case study research. Academy of Management Review, 14(4), 532-550.

Eisenhauer, J. G. (1995). The entrepreneurial decision: Economic theory and empirical evidence. Entrepreneurship: Theory and Practice, 19(4), 67-80.

Evans, J. S. B. (2008). Dual-processing accounts of reasoning, judgment, and social cognition. Annual Review of Psychology, 59, 255-278.

Everatt, J., Steffert, B., Smythe, I., 1999. An eye for the unusual: creative thinking in dyslexics. Dyslexia 5 (1), 28-46.

Eysenck, H. J. (1993). Creativity and personality: Suggestions for a theory. Psychological Inquiry, 4(3), 147-178.

Fauchart, E., \& Gruber, M. (2011). Darwinians, communitarians, and missionaries: The role of founder identity in entrepreneurship. Academy of Management Journal, 54(5), 935-957.

Fisher, S. E., \& Francks, C. (2006). Genes, cognition and dyslexia: learning to read the genome. Trends in Cognitive Sciences, 10(6), 250-257.

Florin, J., Lubatkin, M., \& Schulze, W. (2003). A social capital model of high-growth ventures. Academy of Management Journal, 46(3), 374-384.

Foo, M.D. (2009). Emotions and entrepreneurial opportunity evaluation. Entrepreneurship Theory and Practice, 35(2), 375-393.

Fredrickson, B. L. (1998). What good are positive emotions?. Review of General Psychology, 2(3), 300-319.

Frese, M., \& Gielnik, M. M. (2014). The psychology of entrepreneurship. Annual Review of Organizational Psychology and Organizational Behavior, 1(1), 413-438.

Galaburda, A. M. (1993). Dyslexia and development: Neurobiological aspects of extra-ordinary brains. Harvard University Press. 
Gardner, H. H., Kleinman, N. L., Brook, R. A., Rajagopalan, K., Brizee, T. J., \& Smeeding, J. E. (2006). The economic impact of bipolar disorder in an employed population from an employer perspective. The Journal of Clinical Psychiatry, 67(8), 1209-1218.

Gielnik, M. M., Spitzmuller, M., Schmitt, A., Klemann, D. K., \& Frese, M. (2015). "I put in effort, therefore I am passionate": Investigating the path from effort to passion in entrepreneurship. Academy of Management Journal, 58(4), 1012-1031.

Gimeno, J., Folta, T. B., Cooper, A. C., \& Woo, C. Y. (1997). Survival of the fittest? Entrepreneurial human capital and the persistence of underperforming firms. Administrative Science Quarterly, 750-783.

Goncalo, J., Flynn, F., \& Kim, S. (2010). Are two narcissists better than one? The link between narcissism, perceived creativity, and creative performance. Personality and Social Psychology Bulletin, 36, 1484-1495.

Grand Challenges Canada (2016). Global Mental Health. Available from http://www.grandchallenges.ca/grand-challenges/global-mental-health. [October 19 2016]

Grijalva, E., \& Harms, P. D. (2014). Narcissism: An integrative synthesis and dominance complementarity model. Academy of Management Perspectives, 28(2), 108-127.

Grijalva, E., Harms, P. D., Newman, D., Gaddis, B., \& Fraley, R. C. (2015). Narcissism and leadership: A meta-analytic review of linear and nonlinear relationships. Personnel Psychology, 68(1), 1-47.

Gruber, M. (2007). Uncovering the value of planning in new venture creation: A process and contingency perspective. Journal of Business Venturing, 22(6), 782-807.

Gruber, M., MacMillan, I. C., \& Thompson, J. D. (2008). Look before you leap: Market opportunity identification in emerging technology firms. Management Science, 54(9), 16521665.

Gruber, M., MacMillan, I. C., \& Thompson, J. D. (2013). Escaping the prior knowledge corridor: What shapes the number and variety of market opportunities identified before market entry of technology start-ups?. Organization Science, 24(1), 280-300.

Gunia, B. (2017). The sleep trap: Do sleep problems prompt entrepreneurial motives but undermine entrepreneurial means?. Academy of Management Perspectives. DOI: 10.5465/amp.2016.0159.

Hamilton, B. H. (2000). Does entrepreneurship pay? An empirical analysis of the returns to selfemployment. Journal of Political Economy, 108(3), 604-631.

Harris, J. A., Saltstone, R., \& Fraboni, M. (1999). An evaluation of the job stress questionnaire with a sample of entrepreneurs. Journal of Business and Psychology, 13(3), 447-455.

Hatak, I., \& Ehrenhard, M. (2017). Organizational resilience in a VUCA world: The interplay of leadership and personality characteristics. 2017 PDMA Research Forum. Chicago, USA, 11.11.-12.11.

Hatak, I., \& Snellman, K. (2017). The influence of anticipated regret on business start-up behavior. International Small Business Journal, 35(3), 349-360.

Hatak, I., Kautonen, T. \& Fink, M. (2013). Senior-Unternehmertum. Empirische Evidenz aus 27 europäischen Ländern. Die Betriebswirtschaft, 73(1), 7-26.

Hayden, E. P., Bodkins, M., Brenner, C., Shekhar, A., Nurnberger Jr, J. I., O'Donnell, B., \& Hetrick, W. P. (2008). A multimethod investigation of the behavioral activation system in bipolar disorder. Journal of Abnormal Psychology, 117, 164-170

Haynie, J. M., \& Shepherd, D. (2011). Toward a theory of discontinuous career transition: investigating career transitions necessitated by traumatic life events. Journal of Applied Psychology, 96(3), 501-524. 
Hayward, M. L., Forster, W. R., Sarasvathy, S. D., \& Fredrickson, B. L. (2010). Beyond hubris: How highly confident entrepreneurs rebound to venture again. Journal of Business Venturing, 25(6), 569-578.

Hessels, J., Rietveld, C. A., \& van der Zwan, P. (2014). Unraveling two myths about entrepreneurs. Economics Letters, 122(3), 435-438.

Hessels, J., Rietveld, C.A., Thurik, R., \& van der Zwan, P. (2017). Depression and entrepreneurial exit. Academy of Management Perspectives, doi:10.5465/amp.2016.0183.

Hmieleski, K. M., \& Carr, J. C. (2008). The relationship between entrepreneur psychological capital and new venture performance. i, 28(4), 1.

Hoang, H., \& Gimeno, J. (2010). Becoming a founder: How founder role identity affects entrepreneurial transitions and persistence in founding. Journal of Business Venturing, 25(1), 41-53.

Hoogman, M., Bralten, J., Hibar, D. P., Mennes, M., Zwiers, M. P., Schweren, L. S., ... \& de Zeeuw, P. (2017). Subcortical brain volume differences in participants with attention deficit hyperactivity disorder in children and adults: a cross-sectional mega-analysis. Ti, 4(4), 310319.

Hsu, D. K., Wiklund, J., \& Cotton, R. D. (2017). Success, Failure, and Entrepreneurial Reentry: An Experimental Assessment of the Veracity of Self-Efficacy and Prospect Theory. Entrepreneurship Theory and Practice, 41(1), 19-47.

Iversen, J., Malchow-Møller, N., \& Sørensen, A. (2010). Returns to schooling in selfemployment. Economics Letters, 109(3), 179-182.

Jaarsma, P., \& Welin, S. (2012). Autism as a natural human variation: Reflections on the claims of the neurodiversity movement. Health Care Analysis, 20(1), 20-30.

Jamison, K. R. (2005). Exuberance: The passion for life. Vintage Books USA.

Jenkins, A. S., Wiklund, J., \& Brundin, E. (2014). Individual responses to firm failure: Appraisals, grief, and the influence of prior failure experience. Journal of Business Venturing, 29(1), 17-33.

Jennings, J. E., \& McDougald, M. S. (2007). Work-family interface experiences and coping strategies: Implications for entrepreneurship research and practice. Academy of Management Review, 32(3), 747-760.

Johnson, S. L., \& Miller, I. (1997). Negative life events and time to recovery from episodes of bipolar disorder. Journal of Abnormal Psychology, 106(3), 449-457.

Johnson, S. L., Madole, J., \& Freeman, M. (2018). Mania risk and entrepreneurship: Overlapping personality traits. Academy of Management Perspectives, doi:10.5465/amp.2016.0165.

Kahneman, D. (2011). Thinking, fast and slow. New York: Farrar, Straus and Giroux.

Kaplan, R. (1991). Beyond ambition: How driven managers can lead better and live better. San Francisco, CA: Jossey-Bass Limited.

Kaplan, R. E., \& Kaiser, R. B. (2009). Stop overdoing your strengths. Harvard Business Review, 87(2), 100-103.

Karasek, R. A. (1979). Job demands, job decision latitude, and mental strain: Implications for job redesign. Administrative Science Quarterly, 24, 285-308.

Karolyi, C., Winner, E., Gray, W., \& Sherman, G. F. (2003). Dyslexia linked to talent: Global visual-spatial ability. Brain and Language, 85(3), 427-431.

Kasof, J. (1997). Creativity and breadth of attention. Creativity Research Journal, 10(4), 303315.

Kato, S. \& Wiklund, J. (2011). Doing good to feel good: A theory of entrepreneurial action based in hedonic psychology. Paper presented at the Babson College Entrepreneurship Research Conference, Syracuse, NY. 
Katragadda, S., \& Schubiner, H. (2007). ADHD in children, adolescents, and adults. Primary Care: Clinics in Office Practice, 34(2), 317-341.

Kawachi, I., \& Berkman, L. F. (2001). Social ties and mental health. Journal of Urban Health, 78(3), 458-467.

Kessler, R. C., Aguilar-Gaxiola, S., Alonso, J., Chatterji, S., Lee, S., Ormel, J., ... \& Wang, P. S. (2009). The global burden of mental disorders: an update from the WHO World Mental Health (WMH) surveys. Epidemiology and Psychiatric Sciences, 18(1), 23-33.

Kirk, J., \& Reid, G. (2001). An examination of the relationship between dyslexia and offending in young people and the implications for the training system. Dyslexia, 7(2), 77-84.

Klotz, A. C., Hmieleski, K. M., Bradley, B. H., \& Busenitz, L. W. (2014). New venture teams: A review of the literature and roadmap for future research. Journal of Management, 40(1), 226255.

Kreiser, P. M., Marino, L. D., Kuratko, D. F., \& Weaver, K. M. (2013). Disaggregating entrepreneurial orientation: the non-linear impact of innovativeness, proactiveness and risktaking on SME performance. Small Business Economics, 40(2), 273-291.

Kristof, A. L. (1996). Person-organization fit: An integrative review of its conceptualizations, measurement, and implications. Personnel Psychology, 49(1), 1-49.

Kristof-Brown, A. L., Zimmerman, R. D., \& Johnson, E. C. (2005). Consequences of individuals' fit at work: A meta-analysis of person-job, person-organization, person-group, and person-supervisor fit. Personnel Psychology, 58(2), 281-342.

Kyaga, S., Lichtenstein, P., Boman, M., Hultman, C., Långström, N., \& Landén, M. (2011). Creativity and mental disorder: family study of 300000 people with severe mental disorder. The British Journal of Psychiatry, 199(5), 373-379.

Lasky, A. K., Weisner, T. S., Jensen, P. S., Hinshaw, S. P., Hechtman, L., Arnold, L. E., Murray, D., \& Swanson, J. M. (2016). ADHD in context: Young adults' reports of the impact of occupational environment on the manifestation of ADHD. Social Science \& Medicine, 161,160-168.

Lerner, D., Hunt, R., \& Verheul, I. (2018). Dueling Banjos: Harmony and discord between ADHD and entrepreneurship Academy of Management Perspectives, doi:10.5465/amp.2016.0178.

Lerner, D. (2016). Behavioral disinhibition and nascent venturing: Relevance and initial effects on potential resource providers. Journal of Business Venturing.

Lerner, T. (2017, February 15). Kopplingen mellan ADHD och stress missas ofta. Dagens Nyheter, p. 8.

Levesque, M., Shepherd, D. A., \& Douglas, E. J. (2002). Employment or self-employment: A dynamic utility-maximizing model. Journal of Business Venturing, 17(3), 189-210.

Li, W., Fay, D., Frese, M., Harms, P. D., \& Gao, X. Y. (2014). Reciprocal relationship between proactive personality and work characteristics: A latent change score approach. Journal of Applied Psychology, 99, 948-965.

Lichtenstein, P., Halldner, L., Zetterqvist, J., Sjölander, A., Serlachius, E., Fazel, S., ... \& Larsson, H. (2012). Medication for attention deficit-hyperactivity disorder and criminality. New England Journal of Medicine, 367(21), 2006-2014.

Link, B. G., Yang, L. H., Phelan, J. C., \& Collins, P. Y. (2004). Measuring mental illness stigma. Schizophrenia Bulletin, 30(3), 511-541.

Logan, J. \& Martin, N. (2012). Unusual talent: A study of successful leadership and delegation in entrepreneurs who have dyslexia. Inclusive Practice, 4, 57-76.

Logan, J. (2001). Entrepreneurial success: A study of the incidence of dyslexia in the entrepreneurial population and the influence of dyslexia on success. Ph.D. thesis, unpublished, University of Bristol, UK. 
Logan, J. (2009). Dyslexic entrepreneurs: The incidence; their coping strategies and their business skills. Dyslexia, 15(4), 328-346.

Loomes, G., \& Sugden, R. (1982). Regret theory: An alternative theory of rational choice under uncertainty. The Economic Journal, 92(368), 805-824.

Lumpkin, G. T., \& Dess, G. G. (1996). Clarifying the entrepreneurial orientation construct and linking it to performance. Academy of Management Review, 21(1), 135-172.

Luxton, D. D., McCann, R. A., Bush, N. E., Mishkind, M. C., \& Reger, G. M. (2011). mHealth for mental health: Integrating smartphone technology in behavioral healthcare. Professional Psychology: Research and Practice, 42(6), 505.

Mannuzza, S., Klein, R. G., Bessler, A., Malloy, P., \& LaPadula, M. (1993). Adult outcome of hyperactive boys: educational achievement, occupational rank, and psychiatric status. Archives of General Psychiatry, 50(7), 565-576.

March, J. G. (1991). Exploration and exploitation in organizational learning. Organization Science, 2(1), 71-87.

Maurer, I., \& Ebers, M. (2006). Dynamics of social capital and their performance implications: Lessons from biotechnology start-ups. Administrative Science Quarterly, 51(2), 262-292.

McCubbin, H. I., \& Patterson, J. M. (1983). The family stress process: The double ABCX model of adjustment and adaptation. Marriage \& Family Review, 6(1-2), 7-37.

McEwen, B.S. \& Stellar, E. (1993). Stress and the individual. Mechanisms leading to disease. Archives of Internal Medicine, 153(18), 2093-2101.

McEwen, B.S. (2005). Stressed or stressed out: What is the difference? Journal of Psychiatry and Neuroscience, 30(5), 315-318.

McGrath, R. G. (1999). Falling forward: Real options reasoning and entrepreneurial failure. Academy of Management Review, 24(1), 13-30.

McMullen, J. S., \& Shepherd, D. A. (2006). Entrepreneurial action and the role of uncertainty in the theory of the entrepreneur. Academy of Management Review, 31(1), 132-152.

McPherson, M., Smith-Lovin, L., \& Cook, J. M. (2001). Birds of a feather: Homophily in social networks. Annual review of sociology, 27(1), 415-444.

Miller, D. (2015). A downside to the entrepreneurial personality?. Entrepreneurship Theory and Practice, 39(1), 1-8.

Miller, D., \& Breton-Miller, L. (2017). Underdog Entrepreneurs: A Model of Challenge-Based Entrepreneurship. Entrepreneurship Theory and Practice, 41(1), 7-17.

Miner, J. B. (1994). Role motivation theories. Psychology Press.

Miner, J. B., Smith, N. R., \& Bracker, J. S. (1989). Role of entrepreneurial task motivation in the growth of technologically innovative firms. Journal of Applied Psychology, 74(4), 554-560.

Mitchell, J. R., Friga, P. N., \& Mitchell, R. K. (2005). Untangling the intuition mess: Intuition as a construct in entrepreneurship research. Entrepreneurship Theory and Practice, 29(6), 653679.

Morris, M. E., \& Aguilera, A. (2012). Mobile, social, and wearable computing and the evolution of psychological practice. Professional Psychology: Research and Practice, 43(6), 622-626.

Nicolaou, N., \& Shane, S. (2014). Biology, neuroscience, and entrepreneurship. Journal of Management Inquiry, 23(1), 98-100.

Nicolaou, N., Shane, S., Adi, G., Mangino, M., \& Harris, J. (2011). A polymorphism associated with entrepreneurship: evidence from dopamine receptor candidate genes. Small Business Economics, 36(2), 151-155.

OECD (Organisation for Economic Co-operation and Development). (2013). Mental Health and Work. Sweden. 
Ortega, F. (2009). The cerebral subject and the challenge of neurodiversity. BioSocieties, 4(4), 425-445.

Overton, S. L., \& Medina, S. L. (2008). The stigma of mental illness. Journal of Counseling and Development, 86(2), 143-151.

Ozgen, E., \& Baron, R. A. (2007). Social sources of information in opportunity recognition: Effects of mentors, industry networks, and professional forums. Journal of Business Venturing, 22(2), 174-192.

Pachankis, J. E. (2007). The psychological implications of concealing a stigma: a cognitiveaffective-behavioral model. Psychological Bulletin, 133(2), 328-345.

Pakenham, K. I., Samios, C., \& Sofronoff, K. (2005). Adjustment in mothers of children with Asperger syndrome: An application of the double ABCX model of family adjustment. Autism, 9(2), 191-212.

Parrish, B. P., Cohen, L. H., \& Laurenceau, J. P. (2011). Prospective relationship between negative affective reactivity to daily stress and depressive symptoms. Journal of Social and Clinical Psychology, 30(3), 270-296.

Patzelt, H., \& Shepherd, D. A. (2011). Negative emotions of an entrepreneurial career: Selfemployment and regulatory coping behaviors. Journal of Business Venturing, 26(2), 226-238.

Patzelt, H., Williams, T. A., \& Shepherd, D. A. (2014). Overcoming the walls that constrain us: The role of entrepreneurship education programs in prison. Academy of Management Learning \& Education, 13(4), 587-620.

Perry-Smith, J. E., \& Coff, R. W. (2011). In the mood for entrepreneurial creativity? How optimal group affect differs for generating and selecting ideas for new ventures. Strategic Entrepreneurship Journal, 5, 247-268.

Picard, R. W. (2009). Future affective technology for autism and emotion communication. Philosophical Transactions of the Royal Society B: Biological Sciences, 364(1535), 35753584.

Powell, G. N., \& Eddleston, K. A. (2013). Linking family-to-business enrichment and support to entrepreneurial success: do female and male entrepreneurs experience different outcomes?. Journal of Business Venturing, 28(2), 261-280.

Prottas, D. J., \& Thompson, C. A. (2006). Stress, satisfaction, and the work-family interface: A comparison of self-employed business owners, independents, and organizational employees. Journal of Occupational Health Psychology, 11(4), 366-378.

Puranam, P., Alexy, O., \& Reitzig, M. (2014). What's “new” about new forms of organizing?. Academy of Management Review, 39(2), 162-180.

Rauch, A., \& Frese, M. (2007). Let's put the person back into entrepreneurship research: A metaanalysis on the relationship between business owners' personality traits, business creation, and success. European Journal of Work and Organizational Psychology, 16(4), 353-385.

Rauch, A., \& Hatak, I. (2016). A meta-analysis of different HR-enhancing practices and performance of small and medium sized firms. Journal of Business Venturing, 31(5), 485504.

Rauch, A., Fink, M. \& Hatak, I. (2017). Stress processes: A neglected ingredient in the entrepreneurial process. Academy of Management Perspectives, forthcoming.

Renty, J., \& Roeyers, H. (2007). Individual and marital adaptation in men with autism spectrum disorder and their spouses: The role of social support and coping strategies. Journal of Autism and Developmental Disorders, 37(7), 1247-1255.

Rietveld, C. A., Kippersluis, H., \& Thurik, A. R. (2015). Self-employment and health: Barriers or benefits?. Health Economics, 24(10), 1302-1313. 
Rizvi, S. L., Dimeff, L. A., Skutch, J., Carroll, D., \& Linehan, M. M. (2011). A pilot study of the DBT coach: an interactive mobile phone application for individuals with borderline personality disorder and substance use disorder. Behavior Therapy, 42(4), 589-600.

Robins, R. W., \& Beer, J. S. (2001). Positive illusions about the self: Short-term benefits and long-term costs. Journal of Personality and Social Psychology, 80(2), 340.

Rosenthal, S. A., \& Pittinsky, T. L. (2006). Narcissistic leadership. The Leadership Quarterly, 17(6), 617-633.

Schecklmann, M., Ehlis, A.-C., Plichta, M. M., Romanos, J., Heine, M., Boreatti-Hümmer, A., Jacob, C., \& Fallgatter, A. J. (2008). Diminished prefrontal oxygenation with normal and above-average verbal fluency performance in adult ADHD. Journal of Psychiatric Research, 43(2), 98-106.

Schönfeld, P., Brailovskaia, J., Bieda, A., Zhang, X. C., \& Margraf, J. (2016). The effects of daily stress on positive and negative mental health: Mediation through self-efficacy. International Journal of Clinical and Health Psychology, 16(1), 1-10.

Schonstein, E., \& Verbeek J. H. (2003). Occupational health systematic reviews: An overview. Work, 26(3), 255-8.

Schulze, B. (2007). Stigma and mental health professionals: a review of the evidence on an intricate relationship. International review of Psychiatry, 19(2), 137-155.

Shane, S. A. (2008). The illusions of entrepreneurship: The costly myths that entrepreneurs, investors, and policy makers live by. Yale University Press.

Shane, S., \& Delmar, F. (2004). Planning for the market: business planning before marketing and the continuation of organizing efforts. Journal of Business Venturing, 19(6), 767-785.

Shane, S., Locke, E. A., \& Collins, C. J. (2003). Entrepreneurial motivation. Human Resource Management Review, 13(2), 257-279.

Shepherd, D. A. (2003). Learning from business failure: Propositions of grief recovery for the self-employed. Academy of management Review, 28(2), 318-328.

Shepherd, D. A. (2015). Party On! A call for entrepreneurship research that is more interactive, activity based, cognitively hot, compassionate, and prosocial. Journal of Business Venturing, 30(4), 489-507.

Shepherd, D. A., \& Patzelt, H. (2015). The "heart" of entrepreneurship: The impact of entrepreneurial action on health and health on entrepreneurial action. Journal of Business Venturing Insights, 4, 22-29.

Shepherd, D. A., \& Patzelt, H. (2017). Trailblazing in Entrepreneurship: Creating New Paths for Understanding the Field. Cham: Springer.

Shepherd, D. A., McMullen, J. S., \& Jennings, P. D. (2007). The formation of opportunity beliefs: Overcoming ignorance and reducing doubt. Strategic Entrepreneurship Journal, 1(12), 75-95.

Shepherd, D. A., McMullen, J. S., \& Ocasio, W. (2017). Is that an opportunity? An attention model of top managers' opportunity beliefs for strategic action. Strategic Management Journal, 38(3), 626-644.

Shepherd, D. A., Patzelt, H., \& Wolfe, M. (2011). Moving forward from project failure: Negative emotions, affective commitment, and learning from the experience. Academy of Management Journal, 54(6), 1229-1259.

Shepherd, D. A., Williams, T., Wolfe, M., \& Patzelt, H. (2016). Learning from Entrepreneurial Failure. Cambridge University Press.

Singer, J. (1999). Why can't you be normal for once in your life? From a 'problem with no name' to the emergence of a new category of difference. In M. Corker, \& S. French (Eds), Disability discourse, 59-67. Buckingham: Open UP.

Snowling, M. J. (2000). Dyslexia. Blackwell Publishing. 
Solomon, B. C., \& Jackson, J. J. (2014). The long reach of one's spouse: Spouses' personality influences occupational success. Psychological Science, 25(12), 2189-2198.

Spivack, A., \& McKelvie, A. (2017). Entrepreneurship addiction: Shedding light on the manifestation of the 'dark side' in work behavior patterns. Academy of Management Perspectives, doi:10.5465/amp.2016.0185.

Stephan, U. (2018). Entrepreneurs' mental Health and well-Being: A review and research agenda. Academy of Management Perspectives, doi:10.5465/amp.2017.0001..

Stephan, U., \& Roesler, U. (2010). Health of entrepreneurs vs. employees in a national representative sample. Journal of Occupational and Organizational Psychology, 83(3), 717738.

Tafti, M. A., Hameedy, M. A., \& Baghal, N. M. (2009). Dyslexia, a deficit or a difference: Comparing the creativity and memory skills of dyslexic and nondyslexic students in Iran. Social Behavior and Personality, 37(8), 1009-1016.

Thoits, P. A. (2011). Mechanisms linking social ties and support to physical and mental health. Journal of Health and Social Behavior, 52(2), 145-161.

Thurik, R., Khedhaouria, A., Torrès, O., \& Verheul, I. (2016). ADHD symptoms and entrepreneurial orientation of small firm owners. Applied Psychology, 65(3), 568-586.

Van Vegchel, N., De Jonge, J., Bosma, H., \& Schaufeli, W. (2005). Reviewing the effort-reward imbalance model: drawing up the balance of 45 empirical studies. Social Science \& Medicine, 60(5), 1117-1131.

Verheul, I., Block, J., Burmeister-Lamp, K., Thurik, R., Tiemeier, H., \& Turturea, R. (2015). ADHD-like behavior and entrepreneurial intentions. Small Business Economics, 45(1), 85101.

Wareham, J., \& Sonne, T. (2008). Harnessing the power of autism spectrum disorder (Innovations Case Narrative: Specialisterne). Innovations, 3(1), 11-27.

Wasserman, N. (2006). Stewards, agents, and the founder discount: Executive compensation in new ventures. Academy of Management Journal, 49(5), 960-976.

Weick, K. E. (1995). Sensemaking in organizations (Vol. 3). Sage.

White, H. A., \& Shah, P. (2011). Creative style and achievement in adults with attentiondeficit/hyperactivity disorder. Personality and Individual Differences, 50(5), 673-677.

Wiklund, J., Patzelt, H., \& Dimov, D. (2016). Entrepreneurship and psychological disorders: How ADHD can be productively harnessed. Journal of Business Venturing Insights, 6, 1420.

Wiklund, J., Yu, W., Tucker, R., \& Marino, L. (2017a). ADHD, impulsivity and entrepreneurship. Journal of Business Venturing, 32(6), 627-656.

Wiklund, J., Yu, W., \& Patzelt, H. (2017b). Impulsivity and entrepreneurial action. Academy of Management Perspectives, DOI: 10.5465/amp.2016.0177.

Williams, T. A., Gruber, D. A., Sutcliffe, K. M., Shepherd, D. A., \& Zhao, E. Y. (2017). Organizational Response to Adversity: Fusing Crisis Management and Resilience Research Streams. Academy of Management Annals, 11(2), 733-769. Wilmshurst, L., Peele, M., \& Wilmshurst, L. (2011). Resilience and well-being in college students with and without a diagnosis of ADHD. Journal of Attention Disorders, 15(1), 11-17.

Wood, S. M., \& Bechara, A. (2014). The neuroscience of dual (and triple) systems in decision making. In V. Reyna \& V. Zayas (eds.), The neuroscience of risky decision making. Washington, DC, US: American Psychological Association (pp. 177-202).

World Health Organization (2001). The World Health Report, 2001: Mental Health, New Understanding, New Hope. Geneva: World Health Organization. 
Yang, L. H., Kleinman, A., Link, B. G., Phelan, J. C., Lee, S., \& Good, B. (2007). Culture and stigma: Adding moral experience to stigma theory. Social Science \& Medicine, 64(7), 15241535.

Yin, R.K. (1994). Case study research. Thousand Oaks: Sage.

Zott, C., \& Huy, Q. (2007). Symbolic emphasizing: How entrepreneurs use symbolism to acquire resources. Administrative Science Quarterly, 52(1), 70-105. 
Figure 1: A Sketch of a Model of the Research Opportunities (ROs) on Mental Disorders and Entrepreneurship

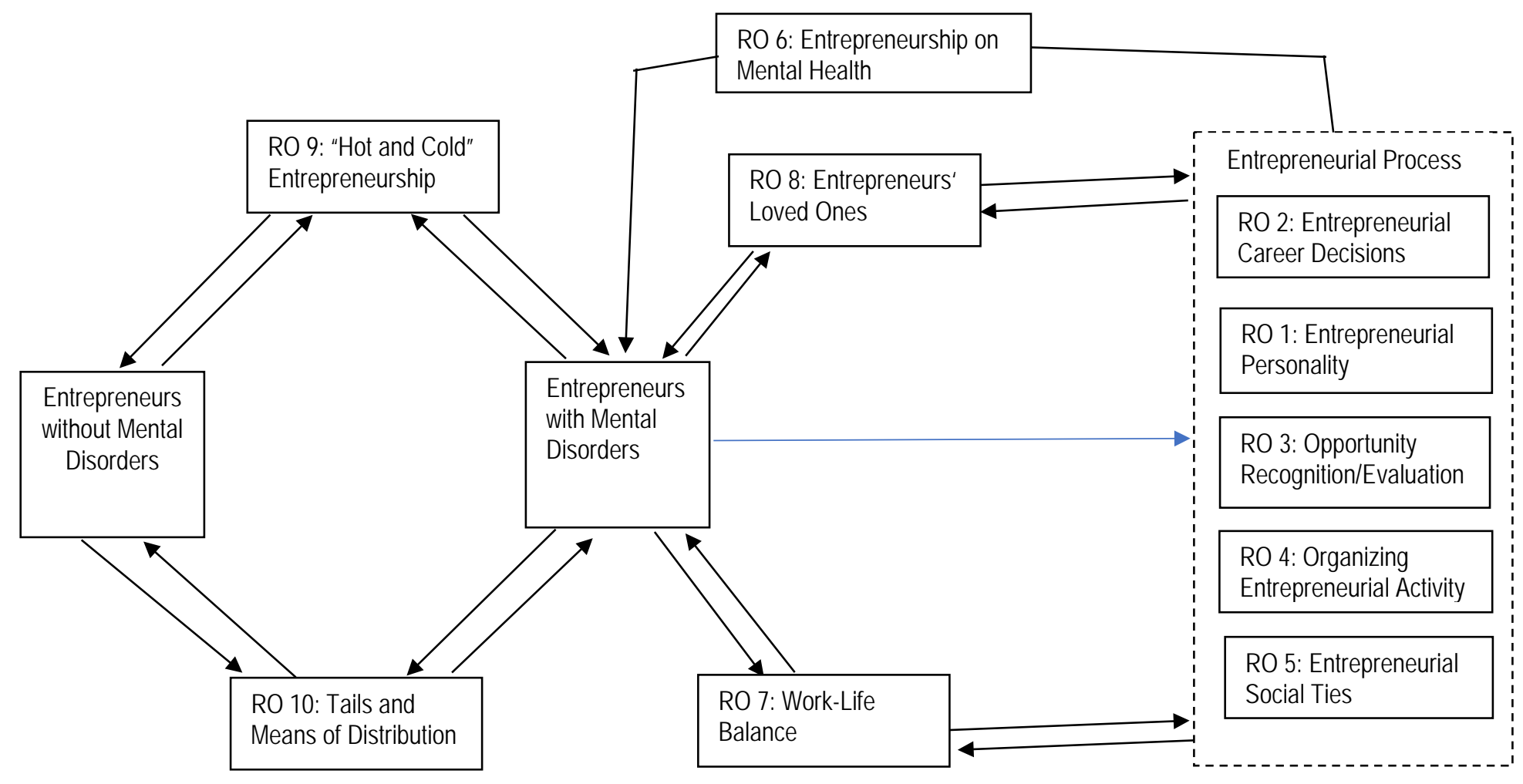


